\title{
PENGARUH UKURAN PERUSAHAAN DAN CORPORATE GOVERNANCE TERHADAP KINERJA KEUANGAN DENGAN PENGUNGKAPAN SUSTAINABILITY REPORT SEBAGAI VARIABEL INTERVENING
}

\author{
Ananda Muliaturrohmah Ikhwani, Irma Paramita Sofia, Karsam Sunaryo \\ Universitas Pembangunan Jaya \\ karsam.sunaryo@upj.ac.id
}

Diterima 28 April 2019, Disetujui 01 Mei 2019

\begin{abstract}
Abstrak
Kinerja keuangan dapat memberikan gambaran mengenai kinerja perusahaan masa lalu dan prospek di masa yang akan datang. Banyak perusahaan yang melakukan kegiatan usaha yang berkaitan dengan alam tetapi tidak mengungkapkan laporan keberlanjutan. Perusahaan yang mempunyai ukuran perusahaan yang besar seharusnya lebih banyak mengungkapkan informasi dibandingkan perusahaan yang berukuran kecil, termasuk pengungkapan mengenai penerapan Corporate Governance dan pengungkapan sustainability report. Dengan pengungkapan yang dilakukan diharapkan menambah kepercayaan masyarakat terhadap perusahaan dan meningkatkan kinerja keuangan perusahaan. Penelitian ini dilakukan untuk memperoleh bukti bahwa ukuran perusahaan dan Corporate Governance berpengaruh terhadap kinerja keuangan, serta peran pengungkapan Sustainability Report sebagai pemediasi hubungan antara variabel-variabel tersebut pada sembilan perusahaan badan usaha milik negara dan sektor pertambangan selama lima tahun (2013-2017). Hasil dari penelitian ini menunjukkan bahwa (1) ukuran perusahaan berpengaruh terhadap kinerja keuangan; (2) Corporate Governance berpengaruh terhadap kinerja keuangan; (3) ukuran perusahaan tidak berpengaruh terhadap pengungkapan sustainability report; (4) Corporate Governance berpengaruh terhadap pengungkapan sustainability report; dan (5) pengungkapan Sustainability Report tidak dapat memediasi pengaruh antara ukuran perusahaan/Corporate Governance terhadap kinerja keuangan.
\end{abstract}

Kata Kunci: ukuran perusahaan, tata kelola perusahaan, komite audit, dewan direksi, laporan berkelanjutan, kinerja keuangan

\begin{abstract}
Financial performance can provide an overview of past performance and future prospects of a company. Many companies carry out business activities related to nature but do not disclose sustainability reports. Companies that have a large company size should disclose more information than small companies, including disclosures about the implementation of Corporate Governance and sustainability reports disclosure. With these disclosures of information, it is expected to increase public trust in the company and improve the company's financial performance. This research aims to obtain evidence that company size and Corporate Governance influence financial performance, and the role of Sustainability Report disclosure as mediating the relationship between these variables in nine state-owned enterprises and the mining sector for five years (2013-2017). The results of this study indicate that (1) company size has effects on financial performance; (2) audit committee has effects on financial performance; (3) the board of directors does not affect financial performance; (4) company size has not affect the disclosure of sustainability report; (5) the audit committee has not affect the disclosure of sustainability report; (6) the board of directors has effect the disclosure of sustainability report; and (7) Sustainability Report disclosure can't mediate the influence between company size/Corporate Governance on financial performance.
\end{abstract}

Keywords: $\quad$ Size Company, Corporate Governance, Audit Committee, The Board of Directors, Sustainability Report Disclosure, Financial Performance. 


\section{PENDAHULUAN}

Kompetisi dalam berbagai sektor usaha menjadi kompetisi global dan terus mengalami perkembangan yang pesat (Karsam, 2017). Perkembangan dunia usaha saat ini yang sarat dengan persaingan menyebabkan seluruh perusahaan berusaha keras untuk memaksimalkan laba dari hasil operasinya demi mempertahankan kelangsungan usaha perusahaan namun tetap harus bisa mengelola risiko dengan baik (Setiawan, 2016). Kemampuan perusahaan untuk menghasilkan laba dapat berdampak pada minat para investor untuk menanamkan dana guna memperluas usahanya (Sawitri et al, 2017).

Adanya peningkatan laba akan mempengaruh kinerja keuangan perusahaan. Kinerja keuangan merupakan gambaran kondisi keuangan perusahaan pada suatu periode tertentu menyangkut aspek penghimpunan dana maupun penyaluran dana (Tambunan dan Prabawani, 2018). Kinerja keuangan suatu perusahaan dapat diartikan sebagai prospek atau masa depan, pertumbuhan, dan potensi perkembangan yang baik bagi perusahaan (Bukhori, 2017). Keberadaan Badan Usaha Milik Negara sangat penting dan strategis tidak hanya sebagai agen pembangunan (agent of development) tetapi juga sebagai perusahaan yang mencari keuntungan (profit) (Saragih, 2014). Badan Usaha Milik Negara adalah badan usaha yang seluruh atau sebagian besar modalnya dimiliki oleh negara serta BUMN yang berbentuk perseroan terbatas yang modalnya terbagi dalam saham yang seluruh atau paling tidak $51 \%$ (lima puluh satu persen) sahamnya dimiliki oleh Negara Republik Indonesia yang tujuan utamanya mengejar keuntungan (Undang-Undang tentang Badan Usaha Milik Negara).

Namun pada saat ini, perusahaan dituntut oleh berbagai pihak dari stakeholder, tidak hanya para investor maupun kreditor saja, namun juga karyawan, supplier, konsumen, masyarakat, lembaga swadaya masyarakat, dan pemerintah untuk lebih transparansi dan akuntabilitas dalam kegiatan yang berhubungan dengan sustainable perusahaan (Adhipradana dan Daljono, 2014).
Terjadinya pergeseran paradigma bisnis, dimana awalnya bisnis hanya dibangun dengan paradigma single $\mathrm{P}$ (Profit), tetapi pandangan ini berubah seiring dengan munculnya berbagai kasus yang merugikan lingkungan maka paradigma bisnis tidak lagi mengacu pada single P (Profit) dan berubah menjadi triple P (Profit, People, Planet) (Aulia dan Syam, 2013).

Keseimbangan antara people-planet-profit, yang dikenal dengan konsep triple bottom line (Wijayanti, 2016). Konsep triple bottom line ini menegaskan bahwa perusahaan ingin mempertahankan keberlangsungan usahanya maka selain mengejar profit juga harus memperhatikan dan terlibat pada upaya pemenuhan kesejahteraan masyarakat atau people sekaligus ikut berkontribusi aktif dalam menjaga kelestarian lingkungan atau planet (Pikiran Rakyat, 2017). Dalam beberapa tahun terakhir sebagian perusahan di Indonesia telah mulai menyeimbangkan antara orientasi keuntungan dan perbaikan lingkungan (Idah, 2013). Oleh karena itu, perusahaan di samping menjalankan aktivitas untuk memperoleh laba atau keuntungan juga harus memiliki tanggung jawab sosial untuk membantu memecahkan masalah-masalah sosial terkait di mana perusahaan itu berada (Khafid dan Mulyaningsih, 2015).

Menurut hasil Proper 2009, terdapat 50 Badan Usaha Milik Negara yang berperingkat buruk Proper yaitu 10 (sepuluh) BUMN berperingkat hitam, 9 (sembilan) BUMN berperingkat merah minus, dan 31 (tiga puluh satu) BUMN berperingkat merah (Antara News, 2009). Seperti pencemaran yang terjadi akibat tumpahnya minyak di Balikpapan oleh PT Pertamina yang menimbulkan kerusakan yang cukup serius bahkan hingga mendapatkan kategori pencemaran berat oleh Wahli Kalimantan Timur (Affan, 2018). Selain pencemaran, PT Pertamina juga mengalami kebocoran pipa penyalur minyak mentah di kawasan RT 04 Kelurahan Nenang, Kecamatan Penajam yang telah mencemari tambak milik masyarakat, serta 885 warga dari 236 keluarga di 
Kelurahan Nenang yang terkena dampak dari kebocoran pipa tersebut (Luciana, 2018). Kerusakan lingkungan lainnya yang dilakukan oleh PT Sinkona Indonesia Lestari (SIL) karena membuang limbah sembarangan serta limbah tersebut mengalir kesaluran air yang mengalir kedaerah persawahan dan kolam milik warga yang berada di Desa Cimanglid, Subang (Putra, 2018).

Kerusakan lingkungan yang terjadi akibat aktivitas bisnis perusahaan memberitahu kita bahwa perusahaan-perusahaan yang tengah berkembang di Indonesia masih banyak yang kurang peduli akan kerugian yang harus ditanggung oleh masyarakat aktibat aktivitas bisnisnya (Aniktia dan Khafid, 2015). Menurut Christine Koblun (2015), banyak kasus kerusakan lingkungan yang terjadi di dunia, perusahaan yang tidak ramah lingkungan memiliki bisnis yang tidak akan berlangsung lama karena citra perusahaan di mata pelanggan dan masyarakat akan menjadi buruk jika terjadi kasus yang terkait dengan kerusakan lingkungan (Prahadi, 2015). Isu-isu sosial dan lingkungan yang beredar dimasyarakat membuat perusahaan melakukan berbagai aktivitas sosial dan perlu mengungkapkannya dalam sustainability reporting (Adhipradana dan Daljono, 2014).

Sejak awal tahun 2000, The Global Reporting Initiative (GRI) merupakan organisasi non-profit multi-stakeholder global yang telah mempromosikan Sustainability Reporting (SR) dan berusaha mengembangkan standar untuk sustainability reporting, yaitu GRI atau G3 Sustainability Reporting Guidelines (Tumewu, 2017). Sustainability reporting adalah laporan keuangan dan non keuangan yang dipublikasikan oleh perusahaan melalui informasi-informasi yang terdapat di dalam ruang lingkup perusahaan dan kegiatan ekonomi dan sosial (Dewi dan Sudana, 2015). Sedangkan menurut Khafid dan Mulyaningsih (2015), pengungkapan Sustainability Report merupakan bentuk komitmen perusahaan dalam mempublikasikan laporan keberlanjutan perusahaan dan berisi informasi tentang pertanggungjawaban perusahaan terhadap lingkungan dan sosial.
Sustainability Report menjadi media bagi perusahaan untuk tidak hanya melaporkan aspek keuangan tetapi melaporkan aspek non-keuangan seperti sosial dan lingkungan kepada pemangku kepentingan (Wijayanti, 2016). Laporan keberlanjutan atau Sustainability Reporting sifatnya sangat penting untuk melihat kinerja perusahaan (Pos Kota, 2016). Sustainability Report sangat diperlukan agar stakeholder termasuk masyarakat, mengetahui segala bentuk tanggung jawab perusahaan kepada masyarakat dan lingkungan (Sari dan Marsono, 2013). Kemampuan perusahaan untuk mengkomunikasikan kegiatan dan kinerjanya secara efektif melalui Sustainability Report dinilai sebagai bentuk akuntabilitas, responsibilitas, dan transparansi perusahaan kepada stakeholders-nya yang dipercaya dapat meningkatkan nilai perusahaan (Wijayanti, 2016).

Agar dapat meminimalisir dampak negatif yang ditimbulkan dari aktivitas bisnis, maka pemerintah mengeluarkan regulasi tentang tanggung jawab sosial dan lingkungan perusahaan. Undang-Undang Pemerintah Nomor 40 Tahun 2007, tentang Perseroan Terbatas Pasal 74 tentang tanggung jawab sosial dan lingkungan yang menungkapkan bahwa perusahaan wajib melaksanakan tanggung jawab sosial dan lingkungan. Didukung dengan Undang-Undang Badan Usaha Milik Negara yang menambahkan, bahwa selain mencari keuntungan, peran BUMN adalah untuk memberikan bimbingan bantuan secara aktif kepada pengusaha golongan lemah, koperasi dan masyarakat. Oleh sebab itu, apabila melihat maksud dan tujuan BUMN tersebut maka sudah menjadi kewajiban dari BUMN untuk mewujudkan kemanfaatan umum dalam bentuk memberikan bimbingan dan bantuan kepada masyarakat atau dapat juga disebut sebagai tanggung jawab sosial dari suatu BUMN (Lubis et al, 2017).

Adanya aturan tegas yang mewajibkan perusahaan yang berkaitan dengan sumber daya alam untuk melakukan tanggung jawab sosial dan lingkungan, hal tersebut mendorong manajer 
perusahaan melakukan pengungkapan sustainability report (Sari dan Marsono, 2013). Setiap tahun jumlah perusahaan yang menungkapkan Sustainability Report semakin bertambah, namun tidak sebanding dengan jumlah seluruh perusahaan yang ada di Indonesia (Adhipradana dan Daljono, 2014). Menurut Sarwono Kusumaatmadja selaku Ketua Tim Juri Sustainability Reporting Award dalam (Media Indonesia, 2016), laporan berkelanjutan sangat penting dalam membangun dan mengembangkan bisnis bersama pemangku kepentingan tetapi, hingga akhir 2016 tercatat hanya 120 perusahaan dari 570 perusahaan yang terdaftar di Bursa Efek Indonesia yang telah menerbitkan laporan berkelanjutan atau sustainability reporting. Sedangkan dari 53 perusahaan Badan Usaha Milik Negara dan perusahaan sektor pertambangan yang terdaftar di Bursa Efek Indonesia, hanya terdapat tujuh belas perusahaan yang mengungkapkan Sustainability Report sepanjang tahun 2011 sampai dengan 2017, tetapi hanya sembilan perusahaan yang telah mengungkapkan Sustainability Report dan aktivitas kegiatan perusahaannya berkaitan dengan sumber daya alam sesuai dengan peraturan Undang-Undang Pemerintah Nomor 40 Tahun 2007 serta melaporkan sustainability reporting secara berturut-turut dari tahun 2013 hingga 2017.

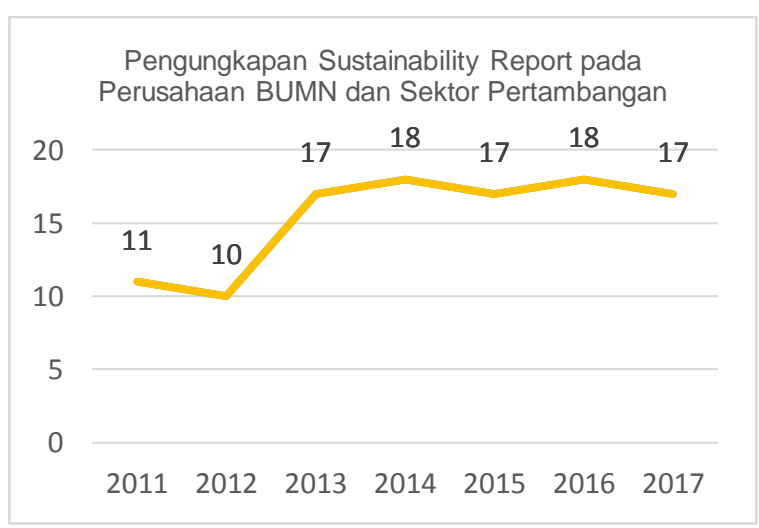

Gambar 1. Tingkat Pengungkapan Sustainability Report Sumber: Data Hasil Observasi, 2018.

Gambar 1 menunjukkan bahwa perusahaan BUMN dan sektor pertambangan belum sepenuhnya sadar terhadap tanggung jawab sosial dan lingkungan perusahaan. Seharusnya perusahaan sektor pertambangan wajib melaporkan Sustainability Report sesuai dengan Undang-Undang serta sesuai dengan UndangUndang Badan Usaha Milik Negara bahwa, perusahaan harus melaksanakan rekstrukturisasi yang merupakan upaya dalam rangka penyehatan BUMN sebagai salah satu langkah strategis untuk memperbaiki kondisi internal perusahaan guna memperbaiki kinerja dan meningkatkan nilai perusahaan.

Perusahaan tanpa disadari dalam melakukan perubahan dalam pencapaian kinerja mempengaruhi ukuran perusahaannya (Tambunan dan Prabawani, 2018). Perusahaan dengan ukuran yang besar lebih banyak mendapat sorotan dari publik dan cenderung lebih banyak mengungkapkan informasi yang lebih luas sebagai upaya menjaga legitimasi perusahaan yang dapat diwujudkan melalui pengungkapan Sustainability Report (Sari dan Marsono, 2013). Perusahaan yang memiliki ukuran yang besar seharusnya mengimplementasikan fungsi pengelolaan perusahaan.

Tata kelola perusahaan diperlukan untuk mendorong terciptanya pasar yang efisien, transparan dan konsisten dengan peraturan perundang-undangan (Komite Nasional Kebijakan Governance, 2006). Berdasarkan code of Corporate Governance yang dikeluarkan oleh Komite Nasioanal Kebijakan Governance (2006) menyatakan fungsi pengelolaan perusahaan yang dilakukaan dewan direksi mencakup lima fungsi yaitu kepengurusan, manajemen risiko, pengendalian internal, komunikasi dan tanggung jawab social (Sari dan Marsono, 2013). Kepedulian perusahaan terhadap lingkungan sekitar adalah tanggung jawab sosial perusahaan yang belakangan ini semakin disoroti dengan tajam oleh berbagai kelompok kepentingan di masyarakat sehingga citra perusahaan dalam risiko jika direksi dan dewan komisaris tidak memperhatikan aspek ini dengan cermat (Daniri, 2014). Adanya komite audit sebagai komite penunjang dalam dewan komisaris dalam perusahaan adalah untuk memastikan penerapan tata kelola perusahaaan sesuai dengan peraturan 
yang dikeluarkan oleh Otoritas Jasa Keuangan Nomor 55/POJK.04/2015, tentang Pembentukan dan Pedoman Pelaksanaan Kerja Komite Audit. Maka dengan frekuensi rapat komite audit yang semakin sering, maka pengawasan yang dilakukan akan semakin baik dan kualitas pengungkapan informasi sosial yang dilakukan semakin luas (Sari dan Marsono, 2013). Perusahaan dengan penerapan good corporate governance yang baik diduga memiliki kemungkinan yang besar untuk melakukan pengungkapan tanggung jawab sosial lingkungan yang bersifat sukarela sebagai suatu upaya pemenuhan kebutuhan stakeholder (Aniktia dan Khafid, 2015).

Menurut Undang-Undang Badan Usaha Milik Negara, dalam melaksanakan tugasnya, Komisaris dan Dewan Pengawas harus mematuhi Anggaran Dasar BUMN dan ketentuan peraturan perundangundangan serta wajib melaksanakan prinsip-prinsip profesionalisme, efisiensi, transparansi, kemandirian, akuntabilitas, pertanggungjawaban, serta kewajaran. Praktik dan pengungkapan tanggung jawab sosial perusahaan merupakan konsekuensi logis dari implementasi konsep Corporate Governance (Tumewu, 2017). Menurut Undang-Undang Badan Usaha Milik Negara, bila penataan hubungan fungsional antara pemerintah selaku regulator dan BUMN selaku badan usaha, termasuk didalamnya penerapan prinsip-prinsip tata kelola perusahaan yang baik dan akan menetapkan arah dalam rangka pelaksanaan kewajiban pelayanan. Serta perusahaan akan mendapat manfaat dari peningkatan komunikasi atas pengungkapan sustainability report karena reaksi pasar yang positif terhadap pengungkapan sustainability report (Ernst and Young, 2016).

Berdasarkan fenomena-fenomena yang terjadi, maka keterkaitan antara variabel ukuran perusahaan, corporate governance, kinerja keuangan serta pengungkapan sustainability report menjadikannya sebuah hal yang menarik untuk diteliti. Peneliti memilih perusahaan Badan Usaha Milik Negara Non-Keuangan dan perusahaan sektor pertambangan karena peneliti ingin melihat adanya pengaruh pengungkapan Sustainability Report terhadap perusahaanperusahaan yang aktivitas perusahaannya berkaitan dengan sumber daya alam. Peneliti juga ingin melihat apakah pengungkapan Sustainability Report dapat memediasi antara ukuran perusahaan dan Corporate Governance terhadap kinerja keuangan. Maksud penelitian ini adalah untuk memperoleh bukti empiris Penungkapan Sustainability Report sebagai Variabel Intervening pada Pengaruh antara Ukuran Perusahaan dan Corporate Governance terhadap Kinerja Keuangan.

\section{KAJIAN TEORI}

\section{Teori Stakeholder}

Istilah stakeholder awalnya diperkenalkan oleh Stanford Research Institute (SRI) yang merujuk pada "those groups without whose support the organization would cease to exist" (Freeman dan Reed, 1983). Sedangkan Donaldson and Preston (1995) berpendapat bahwa stakeholder theory merupakan hal yang berkenaan dengan pengelolaan dan ketatalaksanaan (managerial) dan merekomendasikan sikap, struktur, dan praktik yang apabila dilakukan akan membentuk sebuah filosofi manajemen stakeholder. Stakeholder theory memperluas tanggung jawab organisasi kepada seluruh pemangku kepentingan tidak hanya kepada investor atau pemilik (Donaldson and Preston, 1995). Stakeholder theory merupakan salah satu teori utama yang banyak digunakan untuk mendasari penelitian tentang Sustainability Report (Taringan dan Semuel, 2014).

\section{Teori Legitimasi}

Menurut Dowling dan Pfeffer (1975), legimitasi adalah hal yang penting bagi organisasi, batasan-batasan yang ditekankan oleh norma-norma dan nilai sosial, reaksi terhadap batasan tersebut mendorong pentingnya analisis perilaku organisasi dengan memperhatikan lingkungan (Ghozali and Chariri, 2007). Teori legitimasi menegaskan bahwa perusahaan terus berupaya untuk memastikan bahwa perusahaan 
beroperasi dalam bingkai dan norma yang ada dalam masyarakat atau lingkungan dimana perusahaan berada, dimana perusahaan berusaha untuk memastikan bahwa aktivitas bisnisnya diterima oleh pihak luar sebagai suatu yang sah (Deegan, 2004). Teori legitimasi berfokus pada interaksi antara perusahaan dengan masyarakat yang menjadi landasan bagi perusahaan untuk memperhatikan apa yang menjadi harapan masyarakat dan mampu menyelaraskan dengan normal sosial yang berlaku dimana perusahaan melangsungkan kegiatan bisnisnya (Muallifin dan Priyadi, 2016). Apabila organisasi memberikan kontribusi sosial, maka keberadaan perusahaan dan aktivitas yang dilakukan mendapat "status" dan "restu" dari masyarakat atau lingkungan dimana perusahaan tersebut beroperasi (Wijayanti, 2016).

\section{Kinerja Keuangan}

Kinerja keuangan perusahaan merupakan prestasi yang dicapai perusahaan dalam suatu periode tertentu untuk mencerminkan tingkat kesehatan perusahaan tersebut (Sutrisno, 2013). Sedangkan menurut Hery (2015), pengukuran kinerja keuangan merupakan suatu usaha formal untuk mengevaluasi efisiensi dan efektifitas perusahaan dalam menghasilkan laba dan posisi kas tertentu. Dengan pengukuran kinerja keuangan dapat melihat prospek pertumbuhan dan perkembangan keuangan perusahaan dari mengandalkan sumber daya yang dimilikinya dan perusahaan dikatakan berhasil apabila perusahaan telah mencapai suatu tujuan tertentu yang telah ditetapkan.

Pengukuran kinerja keuangan dilakukan secara bersamaan dengan proses analisis keuangan yang merupakan suatu proses pengkajian kinerja keuangan secara kritis, yang meliputi peninjauan data keuangan, penghitungan, pengukuran, interpretasi, dan pemberian solusi terhadap masalah keuangan perusahaan pada suatu periode tertentu (Hery, 2015). Kinerja keuangan dapat dicerminkan melalui analisis rasio keuangan (Ross, $\mathrm{R}$, and $\mathrm{B}$, 2003). Salah satu jenis rasio adalah rasio profitabilitas. Menurut Hery (2015), rasio profitabilitas merupakan rasio yang digunakan untuk mengukur kemampuan perusahaan dalam menghasilkan laba dari aktivitas normal bisnisnya dan manfaat dari rasio profitabilitas secara keseluruhan adalah:

1) Mengukur kemampuan perusahaan dalam menghasilkan laba selama periode tertentu;

2) Menilai posisi laba perusahaan tahun sebelumnya dengan tahun sekarang;

3) Menilai perkembangan laba dari waktu ke waktu;

4) Mengukur seberapa besar jumlah laba bersih yang akan dihasikan dari setiap rupiah dana yang tertanam dalam total aset.

Rasio profitabilitas terdiri dari dua rasio salah satunya adalah Return on Asset. Return on asset merupakan rasio yang menunjukkan seberapa besar kontribusi aset dalam menciptakan laba bersih dengan mengukur sebesar besar jumlah laba bersih yang akan dihasilkan dari setiap rupiah dana yang tertanam dalam total aset. Semakin tinggi hasil pengembalian atas aset berarti semakin tinggi pula jumlah laba bersih yang dihasilkan dari setiap rupiah dana yang tertanam dalam total aset dan semakin rendah hasil pengembalian atas aset berarti semakin rendah pula jumlah laba bersih yang dihasilkan dari setiap rupiah dana yang tertanam dalam total aset (Hery, 2015).

\section{Ukuran Perusahaan}

Ukuran perusahaan merupakan ukuran mengenai besari kecilnya perusahaan (Khafid dan Mulyaningsih, 2015). Ukuran perusahaan menentukan besarnya jumlah anggota yang berhubungan dengan pemilihan cara pengendalian kegiatan dalam usaha untuk mencapai tujuannya (Torang, 2014). Ukuran perusahaan turut menentukan tingkat kepercayaan investor, membutuhkan kredibilitas yang baik sehingga perusahaan perlu melakukan sumbangsih dalam pertumbuhan sosial dan lingkungan sekitar (Nasir, Ilham, dan Utara, 2014). Ukuran perusahaan dapat dihitung dengan melogaritma naturalkan asset (Nasir, Ilham, dan Utara, 2014). Aset adalah sumber daya yang dimiliki perusahaan yang berguna pada waktu sekarang dan waktu yang akan datang atau 
sumber-sumber ekonomis yang dimiliki perusahaan dan masih akan mendatangkan manfaat di kemudiaan hari (Badriyah, 2015). Menurut Badriyah (2015), aset dibagi menjadi lima antara lain:

1) Harta lancar

2) Harta investasi atau investasi jangka panjang

3) Harta tetap berwujud

4) Harta tetap tidak berwujud

5) Harta lain-lain

\section{Corporate Governance}

Corporate Governance merupakan salah satu mekanisme pengelolaan dalam penerapan Corporate Governance diharapkan memberikan kepercayaan terhadap agen (manajemen) dalam menglola kekayaan pemilik (pemegang saham), dan pemilik menjadi lebih yakin bahwa agen tidak akan melakukan suatu kecurangan untuk kesejahteraan agen, sehingga dapat meminimumkan konflik kepentingan dan meminimumkan biaya keagenan (Tumewu, 2017). Menurut The Walker Review (2009), peran Corporate Governance adalah untuk melindungi dan memajukan kepentingan pemegang saham melalui penetapan arahan strategis perusahaan dengan menunjuk dan memantau manajemen yang mampu untuk mencapai tujuan perusahaan (Solomon, 2013).

\section{Komite Audit}

Komite audit merupakan salah satu dewan pengawasan dari sistem Corporate Governance yang memiliki peran penting dalam mengkoordinasikan anggota-anggotanya agar dapat menjalankan tugas secara efektif dalam hal pengawasan laporan keuangan, pengendalian internal dan pelaksanaan Good Corporate Governance perusahaan (Khafid dan Mulyaningsih, 2015). Menurut Komite Nasional Kebijakan Governance (2002), peran komite audit dalam menerapkan Corporate Governance seperti: 1) mengawasi proses Corporate Governance; 2) memastikan bahwa manajemen senior membudayakan Corporate Governance; 3) memonitor bahwa perusahaan tunduk pada code of conduct; 4) mengerti semua pokok persoalan yang mungkin dapat mempengaruhi kinerja finansial dan non-finansial; 5) memonitor bahwa perusahaan tunduk pada tiap undangundang dan peraturan yang berlaku; 6) mengharuskan auditor internal melaporkan secara tertulis hasil pemeriksaan Corporate Governance dan temuan lainnya. Sedangkan tanggung jawab komite audit dalam Corporate Governance adalah memberikan kepastian, bahwa perusahaan tunduk secara layak pada 2 dan peraturan yang berlaku, melaksanakan urusannya dengan pantas dan mempertahankan kontrol yang efektif terhadap benturan kepentingan dan manipulasi terhadap pegawainya (Komite Nasional Kebijakan Governance, 2002).

\section{Dewan Direksi}

Menurut Undang-Undang Perseroan Terbatas No 40 Tahun 2007, direksi adalah organ perseroan yang berwenang dan bertanggung jawab penuh atas pengurusan perseroan untuk kepentingan perseroan, sesuai dengan maksud dan tujuan perseroan serta mewakili perseroan baik di dala maupun di luar pengendalian sesuai dengan tentuan anggaran dasar. Direksi mempunyai 5 fungsi menurut Komite Nasional Kebijakan Governance yaitu: 1) kepengurusan; 2) manajemen risiko; 3) pengendalian internal; 4) Komunikasi; 5) Tanggung jawab sosial. Dalam menjalankan fungsi tanggung jawab sosial, direksi harus mempunyai perencanaan tertulis yang jelas dan fokus dalam melaksanakan tanggung jawab sosial perusahaan dan dalam rangka mempertahankan kesinambungan usaha perusahaan, direksi harus dapat memastikan dipenuhinya tanggung jawab sosial perusahaan. Menurut Komite Nasional Kebijakan Governance (2006), agar pelaksanaan tugas dewan direksi dapat berjalan secara efektif, perlu dipenuhi prinsip-prinsip seberti berikut:

1) Komposisi direksi harus sedemikian rupa sehingga memungkinkan pengambilan keputusan secara efektif, tepat dan cepatm serta bertindak independen. 
2) Direksi harus professional yaitu berintegritas dan memiliki pengalaman serta kecakapan yang diperlukan untuk menjalankan tugasnya.

3) Direksi bertanggung jawab terhadap pengelolaan perusahaan agar dapat menghasilkan keuntungan (profitability) dan memastikan kesinambungan usaha perusahaan.

4) Direksi mempertanggungjawabkan kepengurusannya dalam RUPS sesusai dengan peraturan perundang-undangan yang berlaku.

\section{Sustainability Report}

Baik stakeholders theory maupun teori legitimasi sama-sama merupakan teori yang menjelaskan motivasi para manajer untuk melakukan Sustainability Report (Wijayanti, 2016). Saat ini implementasi Sustainability Report di Indonesia didukung oleh aturan pemerintah seperti Undang-undang Perseroan Terbatas (PT) nomor 40 tahun 2007. Dalam Undang-undang Perseroan Terbatas (PT) nomor 40 tahun 2007 pasal 74 menyatakan bahwa, perseroan yang menjalankan kegiatan usahanya di bidang dan/atau berkaitan dengan sumber daya alam wajib melaksanakan tanggung jawab sosial dan lingkungan serta dianggarkan dan diperhitungan sebagai biaya yang perseroan laksanakan dengan memperhatikan kepatutan dan kewajaran. Sustainability reporting merupakan suatu bentuk laporan tanggung jawab sosial dan lingkungan yang mengungkapkan mengenai kinerja keuangan perusahaan (Sari dan Marsono, 2013). Pelaporan keberlanjutan membantu organisasi untuk menetapkan tujuan, mengukur kinerja, dan mengelola perubahan dalam rangka membuat operasi mereka lebih berkelanjutan (Global Reporting Initiative, 2013).

Menurut (Global Reporting Initiative, 2018) siklus Sustainability Report yang efektif mencakup program pengumpulan data, komunikasi, dan tanggapan reguler harus menguntungkan semua pihak perusahaan baik internal perusahaan dan eksternal perusahaan.
Manfaat yang didapatkan untuk internal perusahaan mencakup:

1) Meningkatkan pemahaman atas risiko dan peluang

2) Menekankan hubungan antara kinerja keuangan dan non-keuangan

3) Mempengaruhi strategi dan kebijakan manajemen jangka panjang, dan rencana bisnis perusahaan

4) Memperlancar proses, mengurangi biaya dan meningkatkan efisiensi

5) Benchmarking dan menilai kinerja keberlanjutan sehubungan dengan hukum, norma, kode, standar kinerja, dan inisiatif sukarela

6) Menghindari keterlibatan dalam kegagalan lingkungan, sosial dan tata kelola yang sudah dipublikasikan

7) Membandingkann kinerja dengan perusahaan lainnya secara internal

\section{METODE PENELITIAN}

Pendekatan dalam penelitian ini adalah menggunakan pendekatan secara kuantitatif, dan berdasarkan tujuannya, jenis penelitian ini adalah kausal yaitu penelitian yang menjelaskan pengaruh suatu variabel bebas (independent variable dan intervening variable) terhadap variabel terikat (dependent variable). Variabel independen dalam penelitian ini meliputi Ukuran Perusahaana dan Corporate Governance melalui Komite Audit dan Dewan Direksi, untuk variabel moderasi yaitu Penungkapan Sustainability Report serta untuk variabel dependen dalam penelitian ini adalah Kinerja Keuangan.

\section{Definisi dan Operasionalisasi Variabel}

Variabel adalah apa pun yang dapat membedakan atau mengubah nilai yang dapat berbeda dalam berbagai waktu untuk objek atau orang yang sama, atau pada waktu yang sama untuk objek atau orang yang berbeda (Sekaran and Bougie, 2017). Jenis variabel yang digunakan pada penelitian ini adalah variabel bebas atau variabel independen dan variabel terikat atau variabel dependen.

1) Variabel Dependen 
Variabel dependen disebut dalam bahasa Indonesia sebagai variabel terikat, merupakan variabel yang dipengaruhi atau menjadi akibat, karena adanya variabel bebas (Sugiyono, 2012). Variabel dependen yang digunakan dalam penelitian ini adalah kinerja keuangan (Y). Kinerja keuangan dapat memberikan gambaran tentang bagaimana kondisi suatu perusahaan. Perusahaan dengan kemampuan menghasilkan laba yang tinggi akan mempunyai kinerja keuangan yang kuat sehingga memiliki kemampuan lebih untuk melakukan program tanggung jawab sosial dan lingkungan beserta pengungkapannya (Aniktia dan Khafid, 2015). Variabel Kinerja Keuangan diukur dengan dimensi profitabilitas dan menggunakan perhitungan Return On Asset yang diformulasikan sebagai berikut:

$$
\text { Return On Asset }=\frac{\text { Laba Setelah Pajak }}{\text { Total Aktiva }}
$$

\section{2) Variabel Independen}

Variabel independen disebut dalam bahasa Indonesia sebagai variabel bebas yang merupakan variabel yang mempengaruhi atau menjadi sebab perubahannya atau timbulnya variabel dependen (terikat) (Sugiyono, 2012). Variabel independen yang digunakan dalam penelitian ini adalah: (1) Ukuran perusahaan yang difokuskan pada total asset $\left(\mathrm{X}_{1}\right)$; dan (2) Corporate Governance yang difokuskan pada komite audit $\left(\mathrm{X}_{2}\right)$ dan dewan direksi $\left(\mathrm{X}_{3}\right)$.

\section{a. Ukuran Perusahaan}

Perusahaan dengan ukuran yang besar akan lebih diperhatikan oleh publik dan perusahaan yang berukuran besar cenderung mengeluarkan biaya untuk mengungkapkan informasi yang lebih lengkap dan luas untuk menjaga legitimasi perusahaan tersebut (Sari dan Marsono, 2013). Didukung dengan pendapat (Idah, 2013) bahwa semakin besar perusahaan, maka perusahaan cenderung mengungkapan informasi lebih banyak dan memungkinkan perusahaan tersebut untuk mengungkapkan sustainability report. Dalam penelitian ini, indikator yang digunakan untuk mengukur tingkat ukuran perusahaan adalah total aktiva karena ukuran perusahaan merupakan cerminan besar kecilnya perusahaan yang tampak dalam nilai total aset perusahaan pada neraca akhir tahun (Tumewu, 2017). Dengan total aset yang besar, perusahaan memiliki daya yang lebih besar untuk mendapatkan legitimasi dari masyarakat (Adhipradana \& Daljono, 2014).

Ukuran Perusahaan $=$ Logaritma Natural

\section{Total Asset}

\section{b. Komite Audit}

Keberadaan komite audit akan mendorong perusahaan untuk menerbitkan laporan yang lengkap dan berintegritas tinggi (Sari dan Marsono, 2013). Semakin sering komite audit melakukan rapat, maka akan semakin sering para anggota komite audit bertukar pikiran dan pengetahuan mengenai keputusan yang harus diambil demi kepentingan seluruh stakeholder salah satunya keputusan mengenai pengungkapan sosial perusahaan (Aniktia dan Khafid, 2015). Dengan demikian semakin banyak rapat yang dilakukan perusahaan maka komite audit semakin efektif dan mendorong perusahaan untuk melakukan pengungkapan Sustainability Report (Adhipradana dan Daljono, 2014).

\section{Komite Audit $=$ Jumlah Rapat Komite Audit}

\section{c. Dewan Direksi}

Dewan direksi merupakan bagian yang bertanggung jawab penuh terhadap kepentingan perusahaan yang memiliki lima fungsi dan salah satunya adalah tanggung jawab sosial (Komite Nasional Kebijakan Governance, 2006). Dalam memenuhi fungsi tanggung jawab sosial, dewan direksi harus memiliki perencanaan yang baik, lengkap dan fokus serta dapat memastikan dipenuhinya pengungkapan tanggung jawab sosial tersebut. Agar fungsi tersebut berjalan dengan baik maka dewan direksi juga harus melaksanakan rapat yang rutin agar tujuan dewan direksi dapat tercapai. Maka variabel Dewan direksi dalam penelitian ini dikur dengan melihat jumlah rapat selama periode selama satu tahun. 
Dewan Direksi $=\underset{\text { Dumlah Rapat Dewan }}{\text { Direksi }}$

\section{d. Variabel Intervening}

Variabel intervening adalah faktor-faktor yang secara teoritis mempengaruhi fenomena yang diteliti tetapi tidak dapat diukur dan dimanipulasi (Sugiyono, 2014). (Sugiyono, 2014) menambahkan, variabel ini terletak di antara variabel independen dan dependen, sehingga variabel indepeden tidak langsung mempengaruhi berubahnya atau timbulnya variabel dependen. Variabel intervening yang digunakan dalam penelitian ini adalah pengungkapan Sustainability Report (Z).

Sustainability Report adalah cara baru yang banyak digunakan oleh perusahaan untuk mengkomunikasikan pengaruh perusahaan terhadap kinerja sosial, lingkungan, dan ekonomi (Burhan dan Rahmanti, 2012). Dalam penelitian ini, variabel Sustainability Report diukur dengan menghitung skor Sustainability Report Disclosure Index (SRDI) untuk menentukan kelengkapan dalam penerapan triple bottom line. Indeks GRI yang digunakan adalah G3.1 (126 item pengungkapan), G4 (149 item pengungkapan) dan GRI Standards (136 item pengungkapan). Peneliti mencantumkan angka 1 (satu) untuk setiap item yang diungkapkan dan angka 0 (nol) untuk setiap item yang tidak diungkapkan pada indeks GRI. Skor SRDI diformulasikan sebagai berikut:

Skor SRDI $=\frac{\text { Jumlah Item yang diungkapkan }}{\text { Jumlah item yang harus diungkapkan }}$

\section{Metode Analisis}

\section{a. Statistik Deskriptif}

Statistik deskriptif adalah statistik yang digunakan untuk menganalisis data dengan cara mendeskripsikan atau menggambarkan data yang telah terkumpul sebagaimana adanya tanpa bermaksud membuat kesimpulan yang berlaku untuk umum atau generalisasi. Dalam menggunakan statistik deskriptif dapat melihat nilai dari modus, median, mean, desil, presentil, perhitungan penyebaran data melalui perhitungan rata-rata dan standar deviasi (Sugiyono, 2014).

\section{b. Uji Asumsi Klasik}

1) Uji Normalitas

Uji normalitas bertujuan untuk menguji apakah dalam model regresi, variabel pengganggu atau residual memiliki distribusi normal. Ada dua cara untuk mendeteksi apakah residual berdistribusi normal atau tidak yaitu dengan analisis grafik dengan melihat grafik histogram serta menggunakan uji statistik dengan melihat nilai kurtosis dan skewness dari residual (Ghozali I. , 2013).

\section{2) Uji Multikoliniesritas}

Uji multikolinieritas diperlukan untuk mengetahui adanya tidaknya variabel independen yang memiliki kemiripan antar variabel independen dalam suatu model. Kemiripan antar variabel independen akan mengakibatkan korelasi yang sangat kuat. Uji ini juga untuk menghindari kebiasaan dalam proses pengambilan keputusan mengenai pengaruh pada uji parsial masing-masing variabel independen terhadap variabel dependen. Jika VIF yang dihasilkan diantara 1-10 maka tidak terjadi multikolinieritas (Sujarweni, 2016).

3) Uji Heteroskedastisitas

Uji heteroskedastisitas untuk menguji perbedaan variance residual suatu periode pengamatan ke periode pengamatan yang lain. Pengujian pada penelitian ini menggunakan uji grafik plot antara nilai prediksi variabel dependen yaitu ZPRED dengan residualnya SRESID (Sujarweni, 2016). Menurut Sujarweni (2016), cara memprediksi ada tidaknya heteroskedastisitas pada suatu model dapat dilihat dengan pola gambar scatterplot, regresi yang tidak terjadi heteroskedastisitas jika:

- Titik-titik data menyebar di atas dan di bawah atau di sekitar angka 0 .

- Titik-titik data tidak mengumpul hanya di atas atau di bawah saja. 
- Penyebaran titik-titik data tidak boleh membentuk pola bergelombang melebar kemudian menyempit dan melebar kembali.

- Penyebaran titik-titik data tidak berpola.

4) Uji Autokorelasi

Uji autokorelasi bertujuan untuk menguji apakah dalam model regresi linear ada korelasi antara kesalahan pengganggu pada periode $t$ dengan kesalahan pengganggu pada periode $\mathrm{t}-1$ (sebelumnya). Autokorelasi muncul karena observasi yang berurutan sepanjang waktu berkaitan satu sama lainnya. Model regresi yang baik adalah regresi yang bebas dari autokorelasi (Ghozali I. , 2013).

5) Uji Hipotesis

a. Uji Koefisien Determinasi (Adjusted $R$ Square)

Uji koefisien determinasi (Adjusted $R$ Square) pada intinya mengukur seberapa jauh kemampuan model dalam menerangkan variasi variabel terikat. Nilai koefisien determinasi adalah diantara nol dan satu. Nilai Adjusted $R$ Square yang kecil berarti kemampuan variabelvariabel independen dalam menjelaskan variasi variabel dependen amat terbatas. Nilai yang mendekati satu berarti variabel-variabel independen memberikan hampir semua informasi yang dibutuhkan unutk memprediksi variasi variabel dependen. Jika dalam uji empiris didapat nilai adjusted $R$ square negatif, maka nilai adjusted $R$ square dianggap bernilai 0 (nol) (Ghozali I. , 2013).

\section{b. Uji Parsial (Uji T)}

Uji statistik t pada dasarnya menunjukkan seberapa jauh pengaruh satu variabel penjelas secara individual dalam menerangkan variasi variabel terikat (Kuncoro, 2011). Menurut (Ghozali I. , 2013), dasar pengambilan keputusan digunakan dalam uji t adalah sebagai berikut:

1) Jika nilai probabilitas signifikansi $>0,05$, maka hipotesis ditolak. Hipotesis ditolak mempunyai arti bahwa variabel independen tidak berpengaruh signifikan terhadap variabel dependen.
2) Jika nilai probabilitas signifikansi $<0,05$, maka hipotesis diterima. Hipotesis tidak dapat ditolak mempunyai arti bahwa variabel independen berpengaruh signifikan terhadap variabel dependen.

\section{c. Uji Mediasi}

Uji Mediasi dalam penelitian ini dilakukan dengan menggunakan metode penelitian Baron and Kenny (1986). Perbedaan model gambar antara model regresi liniear dengan model analisis variabel intervening adalah sebagai berikut:

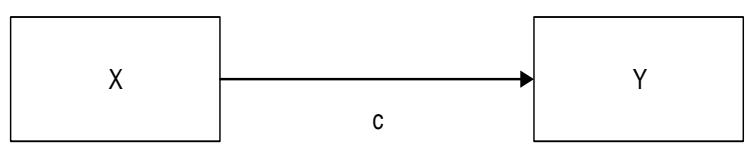

Gambar 2. Panel A

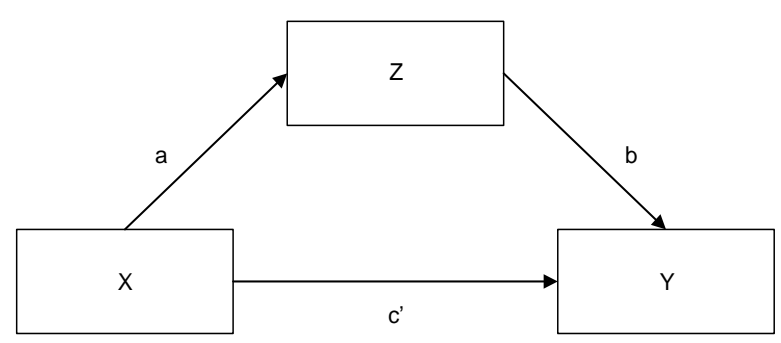

Gambar 3. Panel B

Gambar 2 menunjukkan model regresi liner yang menunjukkan variabel independen (X) berpengaruh langsung terhadap variabel dependen (Y) atau sering disebut direct effect, sedangkan Gambar 3 menggambarkan model analisis intervening dengan bentuk mediasi sederhana yaitu ada pengaruh tidak langsung variabel independen $\mathrm{X}$ ke variabel dependen $\mathrm{Y}$, lewat variabel mediasi (Z) sebagai mediator (Ghozali I. , 2013).

\section{HASIL DAN PEMBAHASAN}

a. Statistik Deskriptif

Tabel 1. Descriptive Statistics

\begin{tabular}{lccccc}
\hline \multicolumn{7}{c}{ N } & Minimum & Maximum & Mean & Std. Deviation \\
\hline LnTA & 45 & 29,30 & 32,15 & 30,7291 &, 79005 \\
\hline JRKA & 45 & 4,00 & 64,00 & 27,3778 & 18,58065 \\
\hline JRDD & 45 & 12,00 & 82,00 & 38,2889 & 18,32363 \\
\hline SRDI & 45 & 0,26 & 0,98 & 0,5100 & 0,17868 \\
\hline ROA & 45 & $-0,03$ & 0,27 & 0,0824 & 0,07290 \\
\hline $\begin{array}{l}\text { Valid N } \\
\text { (listwise) }\end{array}$ & 45 & & & \\
\hline $\begin{array}{l}\text { Sumber: Data yang diolah (2018) } \\
\text { Sumber }\end{array}$
\end{tabular}


1) Dari 45 unit analisis penelitian perusahaan yang memiliki nilai Ln Total asset paling rendah (minimum) adalah PTRO yaitu sebesar 29.30 pada tahun 2016. Sedangkan, perusahaan yang memiliki nilai Ln Total asset paling tinggi (maximum) adalah PGAS yaitu sebesar 32.15 pada tahun 2016. Ln Total asset memiliki nilai rata-rata (mean) sebesar 30.7291 dan standar deviasi (std. deviation) sebesar 0.79005 .

2) Dari 45 unit analisis penelitian yang memiliki JRKA paling rendah (minimum) adalah PTRO yaitu sebanyak dua kali rapat pada tahun 2013-2014. Sedangkan, perusahaan yang memiliki JRKA paling tinggi (maximum) adalah JSMR yaitu sebanyak 64 kali rapat pada tahun 2013. JRKA memiliki nilai rata-rata (mean) sebesar 27,3778 dan standar deviasi (std. deviation) sebesar 18,58065.

3) Dari 45 unit analisis penelitian yang memiliki JRDD paling rendah (minimum) adalah PTRO yaitu sebanyak dua belas kali pada tahun 2013. Sedangkan, perusahaan yang memiliki JRDD paling tinggi (maximum) adalah PTBA yaitu sebanyak 82 kali rapat pada tahun 2014. JRDD memiliki nilai rata-rata (mean) sebesar 38,2889 dan standar deviasi (std. deviation) sebesar 18,32363 .

4) Dari 45 unit analisis penelitian yang memiliki nilai SRDI paling rendah (minimum) adalah TINS yaitu sebesar 0.26 pada tahun 2014. Sedangkan, perusahaan yang memiliki nilai SRDI paling tinggi (maximum) adalah TINS pada tahun 2013 yaitu sebesar 0.98. SRDI memiliki nilai rata-rata (mean) sebesar 0.5100 dan standar deviasi (std. deviation) sebesar 0,17868.

5) Dari 45 unit analisis penelitian yang memiliki nilai ROA paling rendah (minimum) adalah PTRO yaitu sebesar 0.03 pada tahun 2015. Sedangkan, perusahaan yang memiliki nilai ROA paling tinggi (maximum) adalah PTBA yaitu sebesar 0.27 pada tahun 2017. ROA memiliki nilai rata-rata (mean) sebesar
0,0824 dan standar deviasi (std. deviation) sebesar 0,07290.

b. Uji Asumsi Klasik

1. Uji Normalitas

Tabel 2. Uji Normalitas

One-Sample Kolmogorov-Smirnov Test

\begin{tabular}{|c|c|c|}
\hline & $\begin{array}{l}\text { Unstandardize } \\
\text { d Residual }\end{array}$ & $\begin{array}{c}\text { Unstandardize } \\
\text { d Residual }\end{array}$ \\
\hline $\mathbf{N}$ & 45 & 45 \\
\hline \multirow[b]{2}{*}{$\begin{array}{c}\text { Normal } \\
\text { Parameters } \\
(a, b)\end{array}$} & 0.0000000 & 0.0000000 \\
\hline & 0,16795750 & 0,06585866 \\
\hline \multirow{3}{*}{$\begin{array}{c}\text { Most } \\
\text { Extreme } \\
\text { Differences }\end{array}$} & 0,100 & 0,090 \\
\hline & 0,100 & 0,090 \\
\hline & $-0,076$ & $-0,070$ \\
\hline $\begin{array}{l}\text { Kolmogorov } \\
\text {-Smirnov }\end{array}$ & 0,669 & 0,604 \\
\hline $\begin{array}{l}\text { Asymp. Sig. } \\
\text { (2-tailed) }\end{array}$ & 0,762 & 0,859 \\
\hline Keterangan & Normal & Normal \\
\hline \multicolumn{3}{|c|}{ a. Test distribution is Normal. } \\
\hline Sumber: Data yang dio & h (2018) & \\
\hline
\end{tabular}

Tabel 2 menunjukkan nilai profitabilitas atau Asymp. Sig. 2 (2-tailed) dari dua data unstandardized residual. Berdasarkan hasil pengujian pada tabel 4.6, dapat diketahui bahwa nilai profitabilitas yang diperoleh masing-masing data adalah sebesar 0.762 (LnTA, JRKA, JRDD terhadap SRDI) dan 0.859 (LnTA, JRKA, JRDD terhadap ROA). Sehingga, dapat disimpulkan bahwa seluruh data telah terdistribusi normal.

2. Uji Multikolinieritas

Tabel 3. Uji Multikolinieritas

Coefficients (a)

\begin{tabular}{ccc}
\hline \multirow{2}{*}{ Model } & \multicolumn{2}{c}{ Collinearity Statistics } \\
\cline { 2 - 3 } & Tolerance & VIF \\
\hline LnTA & 0,849 & 1,178 \\
\hline JRKA & 0,585 & 1,710 \\
\hline JRDD & 0,583 & 1,715
\end{tabular}

Sumber: Data yang diolah (2018)

Tabel 3 di atas menunjukkan bahwa nilai Tolerance dari variabel ukuran perusahaan (LnTA) dan Corporate Governance (JRKA dan JRDD) adalah sebesar lebih dari 0.10. Sementara itu, nilai VIF dari variabel ukuran perusahaan (LnTA) dan good Corporate Governance (JRKA dan JRDD) adalah sebesar kurang dari 10.00. Sehingga, dapat disimpulkan bahwa data yang diuji tidak terjadi multikolinieritas. 
3. Uji Autokorelasi

Tabel 4. Uji Autokorelasi I

\begin{tabular}{cccccc}
\multicolumn{7}{c}{ Model Summary } \\
Model & $\mathbf{R}$ & $\begin{array}{c}\mathbf{R} \\
\text { Square }\end{array}$ & $\begin{array}{c}\text { Adjusted } \\
\mathbf{R} \\
\text { Square }\end{array}$ & $\begin{array}{c}\text { Std. } \\
\text { Error of } \\
\text { the } \\
\text { Estimate }\end{array}$ & $\begin{array}{c}\text { Durbin- } \\
\text { Watson }\end{array}$ \\
\hline $\mathbf{1}$ &, $429^{\mathrm{a}}$ & 0,184 & 0,124 & 0,06823 & 1,351 \\
\hline
\end{tabular}

a. Predictors: (Constant), JRDD, LnTA, JRKA

b. Dependent Variable: ROA

Sumber: Data yang diolah (2018)

Berdasarkan Tabel 4 di atas, dapat diketahui nilai D-W adalah 1.351, selanjutnya nilai ini akan dibandingkan dengan syarat tersebut bahwa nilai D-W terletak diatas -2 dan dibawah 2 . Sehingga, dapat disimpulkan bahwa hipotesis diterima yang berarti tidak terdapat autokorelasi.

Tabel 5. Uji Autokorelasi II

\begin{tabular}{cccccc}
\multicolumn{5}{c}{ Model Summary } \\
Model & $\mathbf{R}$ & $\begin{array}{c}\mathbf{R} \\
\text { Square }\end{array}$ & $\begin{array}{c}\text { Adjusted } \\
\mathbf{R} \\
\text { Square }\end{array}$ & $\begin{array}{c}\text { Std. } \\
\text { Error of } \\
\text { the } \\
\text { Estimate }\end{array}$ & $\begin{array}{c}\text { Durbin- } \\
\text { Watson }\end{array}$ \\
\hline $\mathbf{1} \quad, 341^{\text {a }}$ & 0,116 & 0,052 & 0,17399 & 1,682 \\
\hline a. Predictors: (Constant), JRDD, LnTA, JRKA \\
b. Dependent Variable: SRDI \\
Sumber: Data yang diolah (2018)
\end{tabular}

Berdasarkan Tabel 5 di atas, dapat diketahui nilai D-W adalah 1.682, selanjutnya nilai ini akan dibandingkan dengan syarat tersebut bahwa nilai D-W terletak diatas -2 dan dibawah 2 . Sehingga, dapat disimpulkan bahwa hipotesis diterima yang berarti tidak terdapat autokorelasi.

4. Uji Heteroskedastisitas

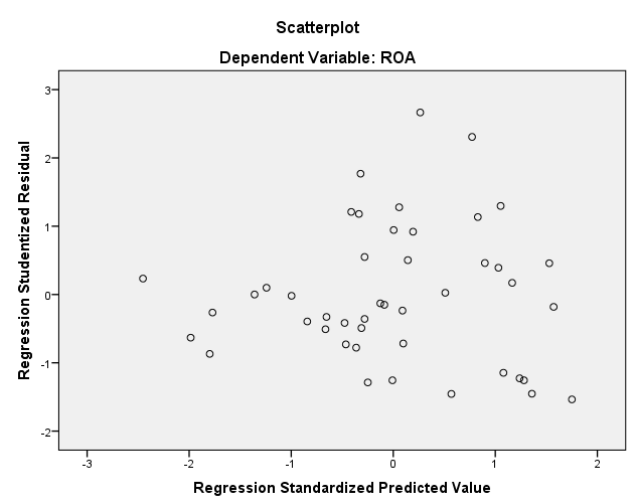

Gambar 4. Grafik Scatterplot I

Sumber: Data yang diolah (2018)

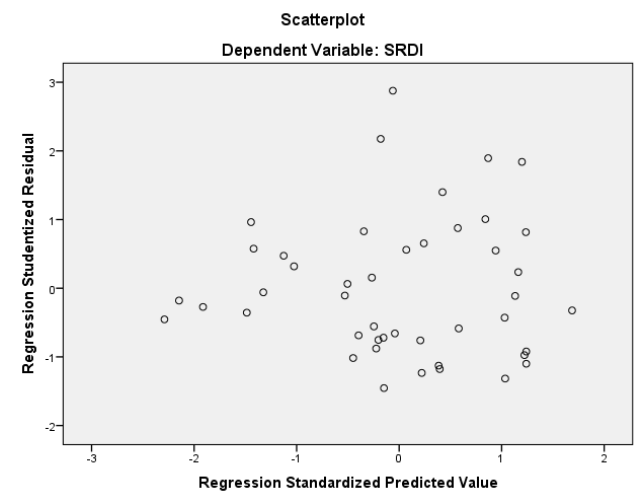

Gambar 5. Grafik Scatterplot II

Sumber: Data yang diolah (2018)

Berdasarkan Gambar diatas, dapat diketahui bahwa titik-titik tidak membentuk suatu pola yang jelas dan titik-titik tersebut menyebar di atas dan di bawah. Maka, dapat disimpulkan bahwa tidak terjadi heteroskedastisitas pada model regresi. Model regresi yang memenuhi persyaratan adalah di mana terdapat persamaan varians dan residual satu pengamatan ke pengamatan yang lain tetap atau disebut homoskedastisitas.

c. Uji Hipotesa

1) Ukuran Perusahaan terhadap Kinerja Keuangan

Tabel 6. Uji R Square I

\begin{tabular}{|c|c|c|c|c|}
\hline \multicolumn{5}{|c|}{ Model Summary } \\
\hline Model & $\mathbf{R}$ & $\begin{array}{c}\text { R } \\
\text { Square }\end{array}$ & $\begin{array}{c}\text { Adjusted } \\
\text { R } \\
\text { Square }\end{array}$ & $\begin{array}{c}\text { Std. } \\
\text { Error of } \\
\text { the } \\
\text { Estimate }\end{array}$ \\
\hline $\mathbf{1}$ & $0,314^{\mathrm{a}}$ & 0,099 & 0,078 & 0,07000 \\
\hline
\end{tabular}

a. Predictors: (Constant), LnTA

b.Dependent Variable: ROA

Sumber: Data yang diolah (2018)

Tabel 6 di atas menunjukkan bahwa nilai Adjusted R Square adalah sebesar 0.078 atau 7.8 persen. Angka Adjusted $R$ Square mengandung arti bahwa ukuran perusahaan berpengaruh terhadap pengungkapan Sustainability Report sebesar 7.8 persen. Sisanya (92.2 persen) dipengaruhi oleh variabel lain di luar model regresi ini. 
Tabel 7. Uji Hipotesis I

Coefficients (a)

\begin{tabular}{ccccccc}
\hline \multirow{2}{*}{ Model } & \multicolumn{2}{c}{$\begin{array}{c}\text { Unstandardized } \\
\text { Coefficients }\end{array}$} & \multicolumn{2}{c}{$\begin{array}{c}\text { Standardized } \\
\text { Coefficients }\end{array}$} & t & Sig. \\
\cline { 2 - 7 } & B & \multicolumn{2}{c}{ Std. Error } & Beta & & \\
\hline (Constant) & -0.809 & 0.411 & & & - & 0.055 \\
\hline LnTA & 0.029 & 0.013 & 0.314 & 2.172 & 0.035 \\
\hline
\end{tabular}

a. Dependent Variable: ROA

Sumber: Data yang diolah (2018)

Tabel 7 di atas menunjukkan bahwa nilai signifikansi adalah 0.035 . Nilai signifikansi yang diperoleh adalah lebih kecil daripada 0.05 (0.035 $<0.05$ ), sehingga dapat dikatakan bahwa secara statistik, $\mathrm{H}_{1}$ dalam penelitian ini diterima. Dengan demikian, dapat disimpulkan bahwa total asset berpengaruh terhadap kinerja keuangan secara signifikan.

2) Jumlah Rapat Komite Audit terhadap Kinerja Keuangan

Tabel 8. Uji R Square II

\begin{tabular}{ccccc} 
Model & \multirow{2}{c}{ Model Summary } \\
\hline $\mathbf{1}$ & $\begin{array}{c}\mathbf{R} \\
\text { Square }\end{array}$ & $\begin{array}{c}\text { Adjusted } \\
\mathbf{R} \\
\text { Square }\end{array}$ & $\begin{array}{c}\text { Std. Error } \\
\text { of the } \\
\text { Estimate }\end{array}$ \\
\hline
\end{tabular}

a. Predictors: (Constant), JRKA

b.Dependent Variable: ROA

Sumber: Data yang diolah (2018)

Tabel 8 di atas menunjukkan bahwa nilai Adjusted R Square adalah sebesar 0.091 atau 9.1 persen. Angka Adjusted $R$ Square mengandung arti bahwa jumlah rapat komite audit berpengaruh terhadap kinerja keuangan sebesar 9.1 persen. Sisanya (90.9 persen) dipengaruhi oleh variabel lain di luar model regresi ini.

Tabel 9. Uji Hipotesis II

Coefficients (a)

\begin{tabular}{lccrrrr}
\hline \multirow{2}{*}{ Model } & \multicolumn{2}{c}{$\begin{array}{c}\text { Unstandardized } \\
\text { Coefficients }\end{array}$} & \multicolumn{2}{c}{$\begin{array}{c}\text { Standardized } \\
\text { Coefficients }\end{array}$} & t & Sig. \\
\cline { 2 - 6 } & B & Std. Error & Beta & & \\
\hline (Constant) & 0,046 & 0,019 & &, 501 &,, 016 \\
\hline JRKA & 0,001 & 0,001 & 0,335 &, 329 &,, 025 \\
\hline
\end{tabular}

a. Dependent Variable: ROA

Sumber: Data yang diolah (2018)

Tabel 9 di atas menunjukkan bahwa nilai signifikansi adalah 0.025 . Nilai signifikansi yang diperoleh adalah lebih kecil daripada 0.05 (0.025 $<0.05$ ), sehingga dapat dikatakan bahwa secara statistik, $\mathrm{H}_{2}$ dalam penelitian ini diterima. Dengan demikian, dapat disimpulkan bahwa jumlah rapat komite audit berpengaruh terhadap kinerja keuangan secara signifikan.

3) Jumlah Rapat Dewan Direksi terhadap Kinerja Keuangan

Tabel 10. Uji R Square III

Model Summary

\begin{tabular}{ccccc}
\hline Model & $\mathbf{R}$ & $\begin{array}{c}\mathbf{R} \\
\text { Square }\end{array}$ & $\begin{array}{c}\text { Adjusted } \\
\mathbf{R} \\
\text { Square }\end{array}$ & $\begin{array}{c}\text { Std. } \\
\text { Error of } \\
\text { the } \\
\text { Estimate }\end{array}$ \\
\hline $\mathbf{1}$ & $0,114^{\mathrm{a}}$ & 0,013 & $-0,010$ & 0,07326 \\
\hline
\end{tabular}

a. Predictors: (Constant), JRDD

b.Dependent Variable: ROA

Sumber: Data yang diolah (2018)

Tabel 10 di atas menunjukkan bahwa nilai Adjusted $R$ Square adalah sebesar -0.010 atau 0 persen. Angka Adjusted $R$ Square mengandung arti bahwa jumlah rapat dewan direksi berpengaruh terhadap kinerja keuangan sebesar 0 persen. Sisanya (100 persen) dipengaruhi oleh variabel lain di luar model regresi ini.

Tabel 11. Uji Hipotesis III

\begin{tabular}{|c|c|c|c|c|c|}
\hline \multicolumn{6}{|c|}{ Coefficients (a) } \\
\hline \multirow{2}{*}{ Model } & \multicolumn{2}{|c|}{$\begin{array}{l}\text { Unstandardized } \\
\text { Coefficients }\end{array}$} & $\begin{array}{c}\text { Standardized } \\
\text { Coefficients }\end{array}$ & $\mathbf{t}$ & \multirow[t]{2}{*}{ Sig. } \\
\hline & B & & Std. Error & Beta & \\
\hline $\begin{array}{r}\text { (Cons } \\
\text { tant) }\end{array}$ & 0,065 & 0,02 & & 2,546 & 0,015 \\
\hline $\begin{array}{l}\text { JRD } \\
\text { D }\end{array}$ & 0,000 & 0,00 & 0,114 & 0,756 & 0,454 \\
\hline
\end{tabular}

a. Dependent Variable: ROA

Sumber: Data yang diolah (2018)

Tabel 11 di atas menunjukkan bahwa nilai signifikansi adalah 0.454 . Nilai signifikansi yang diperoleh adalah lebih besar daripada 0.05 (0.454 > 0.05), sehingga dapat dikatakan bahwa secara statistik, $\mathrm{H}_{3}$ dalam penelitian ini ditolak. Dengan demikian, dapat disimpulkan bahwa jumlah rapat dewan direksi tidak berpengaruh terhadap kinerja keuangan secara signifikan.

4) Ukuran Perusahaan terhadap Pengungkapan Sustainability Report

Tabel 12. Uji R Square IV

\begin{tabular}{|c|c|c|c|c|}
\hline \multicolumn{5}{|c|}{ Model Summary } \\
\hline Model & $\mathbf{R}$ & $\begin{array}{c}\text { R } \\
\text { Square }\end{array}$ & $\begin{array}{c}\text { Adjusted } \\
\text { R } \\
\text { Square }\end{array}$ & $\begin{array}{c}\text { Std. } \\
\text { Error of } \\
\text { the } \\
\text { Estimate }\end{array}$ \\
\hline 1 & $0,092^{\mathrm{a}}$ & 0,009 & $-0,015$ & 0,17998 \\
\hline
\end{tabular}

a. Predictors: (Constant), LnTA

b. Dependent Variable: SRDI

Sumber: Data yang diolah (2018) 
Tabel 12 di atas menunjukkan bahwa nilai Adjusted $R$ Square adalah sebesar -0.015 atau 0 persen. Angka Adjusted $R$ Square mengandung arti bahwa ukuran perusahaan berpengaruh terhadap pengungkapan Sustainability Report sebesar 0 persen. Sisanya $(100$ persen $)$ dipengaruhi oleh variabel lain di luar model regresi ini.

Tabel 13. Uji Hipotesis IV

\begin{tabular}{|c|c|c|c|c|c|}
\hline \multicolumn{6}{|c|}{ Coefficients (a) } \\
\hline \multirow{2}{*}{ Model } & \multicolumn{2}{|c|}{$\begin{array}{l}\text { Unstandardized } \\
\text { Coefficients }\end{array}$} & \multirow{2}{*}{$\begin{array}{c}\text { Standardized } \\
\text { Coefficients }\end{array}$} & \multirow{2}{*}{$\mathbf{t}$} & \multirow{2}{*}{ Sig. } \\
\hline & B & $\begin{array}{l}\text { Std. } \\
\text { Error }\end{array}$ & & & \\
\hline (Constant) & 1.151 & 1.056 & & 1.091 & 0.282 \\
\hline LnTA & $\begin{array}{c}- \\
0.021\end{array}$ & 0.034 & -0.92 & $\begin{array}{c}- \\
0.608\end{array}$ & 0.547 \\
\hline
\end{tabular}

b. Predictors: (Constant), LnTA

Sumber: Data yang diolah (2018)

Tabel 13 di atas menunjukkan bahwa nilai signifikansi adalah 0.547 . Nilai signifikansi yang diperoleh adalah lebih besar daripada 0.05 (0.547 > 0.05), sehingga dapat dikatakan bahwa secara statistik, $\mathrm{H}_{4}$ dalam penelitian ini ditolak. Dengan demikian, dapat disimpulkan bahwa total asset tidak berpengaruh terhadap pengungkapan Sustainability Report secara signifikan.

5) Jumlah Rapat Komite Audit terhadap Pengungkapan Sustainability Report

Tabel 14. Uji R Square V

Model Summary

\begin{tabular}{lcccc}
\hline Model & $\mathbf{R}$ & $\begin{array}{c}\mathbf{R} \\
\text { Square }\end{array}$ & $\begin{array}{c}\text { Adjusted } \\
\mathbf{R} \\
\text { Square }\end{array}$ & $\begin{array}{c}\text { Std. } \\
\text { Error of } \\
\text { the } \\
\text { Estimate }\end{array}$ \\
\hline $\mathbf{1}$ & $0,141^{\mathrm{a}}$ & 0,020 & $-0,003$ & 0,17895 \\
\hline a. & Predictors: (Constant), JRKA & &
\end{tabular}

Sumber: Data yang diolah (2018)

Tabel 14 di atas menunjukkan bahwa nilai Adjusted $R$ Square adalah sebesar -0.003 atau 0 persen. Angka Adjusted $R$ Square mengandung arti bahwa jumlah rapat komite audit berpengaruh terhadap kinerja keuangan sebesar 0 persen. Sisanya (100.0 persen) dipengaruhi oleh variabel lain di luar model regresi ini.
Tabel 15. Uji Hipotesis V

Coefficients (a)

\begin{tabular}{lccccc}
\hline \multirow{2}{*}{ Model } & \multicolumn{2}{c}{$\begin{array}{c}\text { Unstandardized } \\
\text { Coefficients }\end{array}$} & $\begin{array}{c}\text { Standardized } \\
\text { Coefficients }\end{array}$ & t & Sig. \\
\cline { 2 - 6 } & B & $\begin{array}{c}\text { Std. } \\
\text { Error }\end{array}$ & Beta & & \\
\hline (Constant) & 0,547 & 0,048 & &, 428 & 1,000 \\
\hline JRKA & $-0,001$ & 0,001 & $-0,141$ &, 932 & 1,356 \\
\hline
\end{tabular}

a. Dependent Variable: SRDI

Sumber: Data yang diolah (2018)

Tabel 15 di atas menunjukkan bahwa nilai signifikansi adalah 0.356. Nilai signifikansi yang diperoleh adalah lebih besar daripada 0.05 $(0.356>0.05)$, sehingga dapat dikatakan bahwa secara statistik, $\mathrm{H}_{5}$ dalam penelitian ini ditolak. Dengan demikian, dapat disimpulkan bahwa jumlah rapat komite audit tidak berpengaruh terhadap pengungkapan Sustainability Report secara signifikan.

6) Jumlah Rapat Dewan Direksi terhadap Pengungkapan Sustainability Report

Tabel 16. Uji R Square VI

\begin{tabular}{ccccc} 
& & \multicolumn{3}{c}{ Model Summary } \\
\hline Model & $\mathbf{R}$ & $\begin{array}{c}\mathbf{R} \\
\text { Square }\end{array}$ & $\begin{array}{c}\text { Adjusted } \\
\mathbf{R} \\
\text { Square }\end{array}$ & $\begin{array}{c}\text { Std. } \\
\text { Error of } \\
\text { the } \\
\text { Estimate }\end{array}$ \\
\hline $\mathbf{1}$ & $0,330^{\mathrm{a}}$ & 0,109 & 0,088 & 0,17063
\end{tabular}

a. Predictors: (Constant), JRDD

Sumber: Data yang diolah (2018)

Tabel 16 di atas menunjukkan bahwa nilai Adjusted $R$ Square adalah sebesar 0.088 atau 8.8 persen. Angka Adjusted $R$ Square mengandung arti bahwa jumlah rapat dewan direksi berpengaruh terhadap kinerja keuangan sebesar 8.8 persen. Sisanya (91.2 persen) dipengaruhi oleh variabel lain di luar model regresi ini.

Tabel 17. Uji Hipotesis VI

$$
\text { Coefficients (a) }
$$

\begin{tabular}{lrrrrr}
\hline \multirow{2}{*}{ Model } & \multicolumn{2}{c}{$\begin{array}{c}\text { Unstandardized } \\
\text { Coefficients }\end{array}$} & $\begin{array}{c}\text { Standardized } \\
\text { Coefficients }\end{array}$ & t & Sig. \\
\cline { 2 - 5 } & B & $\begin{array}{c}\text { Std. } \\
\text { Error }\end{array}$ & Beta & & \\
\hline Zonstant) & 0,633 & 0,059 & & 548 & 0,000 \\
\hline RDD & 9,003 & 0,001 & $-0,330$ & 292 & 5,027 \\
\hline
\end{tabular}

a. Dependent Variable: SRDI

Sumber: Data yang diolah (2018)

Tabel 17 di atas menunjukkan bahwa nilai signifikansi adalah 0.027 . Nilai signifikansi yang diperoleh adalah lebih kecil daripada 0.05 (0.027 $<0.05$ ), sehingga dapat dikatakan bahwa secara statistik, $\mathrm{H}_{6}$ dalam penelitian ini diterima. 
Dengan demikian, dapat disimpulkan bahwa jumlah rapat dewan direksi berpengaruh terhadap pengungkapan Sustainability Report secara signifikan.

7) Ukuran Perusahaan dan Corporate Governance terhadap Kinerja Keuangan

Tabel 18. Uji R Square VII

\begin{tabular}{ccccc}
\multicolumn{4}{c}{ Model Summary } \\
Model & R & $\begin{array}{c}\text { R } \\
\text { Square }\end{array}$ & $\begin{array}{c}\text { Adjusted } \\
\text { R Square }\end{array}$ & $\begin{array}{c}\text { Std. } \\
\text { Error of } \\
\text { the } \\
\text { Estimat } \\
\text { e }\end{array}$ \\
\hline 1 & $0,429^{\mathrm{a}}$ & 0,184 & 0,124 & 0,06823
\end{tabular}

a. Predictors: (Constant), JRDD, LnTA, JRKA

Sumber: Data yang diolah (2018)

Tabel 18 di atas menunjukkan bahwa nilai Adjusted $R$ Square adalah sebesar 0.124 atau 12.4 persen. Angka Adjusted $R$ Square mengandung arti bahwa ukuran perusahaan dan corporate governance melalui jumlah rapat komite audit dengan jumlah rapat dewan direksi berpengaruh terhadap kinerja keuangan sebesar 12.4 persen. Sisanya (87.6 persen) dipengaruhi oleh variabel lain di luar model regresi ini.

Tabel 19. Uji Hipotesis VII

Coefficients (a)

\begin{tabular}{|c|c|c|c|c|c|}
\hline \multirow{2}{*}{ Model } & \multicolumn{2}{|c|}{$\begin{array}{l}\text { Unstandardize } \\
\text { d Coefficients }\end{array}$} & \multirow{2}{*}{$\begin{array}{c}\begin{array}{c}\text { Standardiz } \\
\text { ed } \\
\text { Coefficient } \\
\text { s }\end{array} \\
\text { Beta }\end{array}$} & \multirow{2}{*}{$t$} & \multirow{2}{*}{ Sig } \\
\hline & B & $\begin{array}{c}\text { Std. } \\
\text { Error }\end{array}$ & & & \\
\hline Constant & $-0,656$ & 0,426 & & $-1,540$ & 0,131 \\
\hline LnTA & 0,024 & 0,014 & 0,258 & 1,683 & 0,100 \\
\hline RKA & 0,001 & 0,001 & 0,381 & 2,066 & 0,045 \\
\hline RDD & $-0,001$ & 0,001 & $-0,217$ & $-1,172$ & 0,248 \\
\hline
\end{tabular}

Tabel 19 di atas menunjukkan bahwa nilai signifikansi dari total asset yang diperoleh adalah lebih besar daripada $0.05(0.100>0.05)$, untuk nilai signifikansi jumlah rapat komite audit yang diperoleh adalah lebih kecil daripada $0.05(0.045<0.05)$, dan nilai signifikansi jumlah rapat dewan direksi yang diperoleh adalah lebih besar daripada 0.05 (0.248 > 0.05). Sengan demikian, dapat disimpulkan bahwa hanya jumlah rapat komite audit yang memiliki pengaruh terhadap kinerja keuangan secara signifikan, sedangkan total asset dan jumlah rapat dewan direksi tidak memiliki pengaruh terhadap kinerja keuangan secara signifikan.

8) Ukuran Perusahaan dan Corporate Governance terhadap Pengungkapan Sustainability Report

Tabel 20. Uji R Square VIII

\begin{tabular}{lcccc}
\multicolumn{5}{c}{ Model Summary } \\
\hline Model & $\mathbf{R}$ & $\begin{array}{c}\mathbf{R} \\
\text { Square }\end{array}$ & $\begin{array}{c}\text { Adjusted } \\
\text { R Square }\end{array}$ & $\begin{array}{c}\text { Std. Error } \\
\text { of the } \\
\text { Estimate }\end{array}$ \\
\hline $\mathbf{1}$ & $341^{\mathrm{a}}$ & 0,116 & 0,052 & 0,17399 \\
\hline a. & Predictors: (Constant), JRDD, LnTA, JRKA \\
Sumber: Data yang diolah (2018)
\end{tabular}

Tabel 20 di atas menunjukkan bahwa nilai Adjusted $R$ Square adalah sebesar 0.052 atau 5.2 persen. Angka Adjusted $R$ Square mengandung arti bahwa ukuran perusahaan dan corporate governance melalui jumlah rapat komite audit dengan jumlah rapat dewan direksi berpengaruh terhadap pengungkapan sustainability report sebesar 5.2 persen. Sisanya (94.8 persen) dipengaruhi oleh variabel lain di luar model regresi ini.

Tabel 21. Uji Hipotesis VIII

Coefficients (a)

\begin{tabular}{cccccc}
\hline & \multicolumn{2}{c}{$\begin{array}{c}\text { Unstandardized } \\
\text { Coefficients }\end{array}$} & $\begin{array}{c}\text { Standardized } \\
\text { Coefficients }\end{array}$ & t & Sig. \\
\cline { 2 - 6 } & B & $\begin{array}{c}\text { Std. } \\
\text { Error }\end{array}$ & Beta & & \\
\hline (Constant) & 0,549 & 1,087 & & 0,505 & 0,616 \\
\hline LnTA & 0,003 & 0,036 & 0,012 & 0,074 & 0,941 \\
\hline JRKA & 0,001 & 0,002 & 0,109 & 0,567 & 0,574 \\
\hline JRDD & $-0,004$ & 0,002 & $-0,403$ & 2,094 & 0,042 \\
\hline a. Dependent Variable: SRDI & & & \\
Sumber: Data yang diolah (2018) & & & &
\end{tabular}

Tabel 21 di atas menunjukkan bahwa nilai signifikansi dari total asset yang diperoleh adalah lebih besar daripada $0.05(0.941>0.05)$, untuk nilai signifikansi jumlah rapat komite audit yang diperoleh adalah lebih besar daripada 0.05 (0.574>0.05), dan nilai signifikansi jumlah rapat dewan direksi yang diperoleh adalah lebih kecil daripada 0.05 (0.042>0.05). Sengan demikian, dapat disimpulkan bahwa hanya jumlah rapat dewan direksi yang memiliki pengaruh terhadap pengungkapan sustainability report secara signifikan, sedangkan total asset dan jumlah rapat komite audit tidak memiliki pengaruh terhadap pengungkapan sustainability report secara signifikan. 
9) Pengungkapan Sustainability Report sebagai Mediasi antara Ukuran Perusahaan dan Corporate Governance terhadap Kinerja Keuangan

Tabel 22. Uji Hipotesis I

\begin{tabular}{lcccc} 
Model & R & $\begin{array}{c}\text { Rodel Summary } \\
\text { Square }\end{array}$ & $\begin{array}{c}\text { Adjusted } \\
\text { R Square }\end{array}$ & $\begin{array}{c}\text { Std. } \\
\text { Error of } \\
\text { the } \\
\text { Estimate }\end{array}$ \\
\hline $\mathbf{1}$ & $0,432^{\mathrm{a}}$ & 0,187 & 0,105 & 0,06896 \\
\hline
\end{tabular}

b. Predictors: (Constant), J SRDI, LnTA, JRKA, JRDD

Sumber: Data yang diolah (2018)

Tabel 22 di atas menunjukkan bahwa nilai Adjusted $R$ Square adalah sebesar 0.105 atau 10.5 persen. Angka Adjusted $R$ Square mengandung arti bahwa ukuran perusahaan, corporate governance melalui jumlah rapat komite audit dengan jumlah rapat dewan direksi, dengan pengungkapan sustainability report berpengaruh terhadap kinerja keuangan sebesar 10.5 persen. Sisanya (89.5 persen) dipengaruhi oleh variabel lain di luar model regresi ini.

Tabel 23. Uji Hipotesis IX

\begin{tabular}{|c|c|c|c|c|c|}
\hline \multirow{3}{*}{ Model } & \multicolumn{3}{|c|}{ Coefficients (a) } & \multirow{3}{*}{$\mathbf{t}$} & \multirow{3}{*}{ Sig. } \\
\hline & \multicolumn{2}{|c|}{$\begin{array}{l}\text { Unstandardize } \\
\text { d Coefficients }\end{array}$} & \multirow{2}{*}{$\begin{array}{c}\begin{array}{c}\text { Standar } \\
\text { dized } \\
\text { Coefficie } \\
\text { nts }\end{array} \\
\text { Beta }\end{array}$} & & \\
\hline & B & $\begin{array}{l}\text { Std. } \\
\text { Error }\end{array}$ & & & \\
\hline (Constant & $-0,644$ & 0,432 & & $-1,490$ & 0,144 \\
\hline LnTA & 0,024 & 0,014 & 0,258 & 1,670 & 0,103 \\
\hline JRKA & 0,002 & 0,001 & 0,387 & 2,069 & 0,045 \\
\hline JRDD & $-0,001$ & 0,001 & $-0,239$ & $-1,217$ & 0,231 \\
\hline SRDI & $-0,023$ & 0,062 & $-0,056$ & $-0,369$ & 0,714 \\
\hline
\end{tabular}

Tabel 23 di atas menunjukkan bahwa nilai signifikansi dari total asset yang diperoleh adalah lebih besar daripada $0.05(0.103>0.05)$, untuk nilai signifikansi jumlah rapat komite audit yang diperoleh adalah lebih kecil daripada $0.05(0.045<0.05)$, untuk nilai signifikansi jumlah rapat dewan direksi yang diperoleh adalah lebih besar daripada $0.05(0.231>0.05)$, untuk nilai signifikansi pengungkapan sustainability report yang diperoleh adalah lebih besar daripada 0.05 (0.714). Sengan demikian, dapat disimpulkan bahwa hanya jumlah rapat komite audit yang memiliki pengaruh terhadap kinerja keuangan secara signifikan, sedangkan total asset, jumlah rapat komite audit, dan pengungkapan sustainability report tidak memiliki pengaruh terhadap kinerja keuangan secara signifikan.

d) Uji Mediasi

1) Ukuran Perusahaan terhadap Kinerja Keuangan

Mengacu pada prosedur pengujian peran variabel intervening yang dikemukakan oleh Baron dan Kenny (1986), maka berikut ini adalah langkah-langkah untuk mengetahui pengujian hipotesis $\left(\mathrm{H}_{7}\right)$ yang dilakukan dengan langkah-langkah berikut:

Tabel 24. Uji Mediasi I

\begin{tabular}{lccccc}
\hline \multirow{2}{*}{ Model } & \multicolumn{2}{c}{$\begin{array}{c}\text { Unstandardized } \\
\text { Coefficients }\end{array}$} & $\begin{array}{c}\text { Standardize } \\
\mathbf{d} \\
\text { Coefficients }\end{array}$ & T & Sig. \\
\cline { 2 - 4 } & B & $\begin{array}{c}\text { Std. } \\
\text { Error }\end{array}$ & Beta & & \\
\hline
\end{tabular}

\begin{tabular}{|c|c|c|c|c|c|}
\hline \multicolumn{6}{|c|}{$\begin{array}{l}\text { Langkah Pertama } \\
\text { Outcome: ROA }\end{array}$} \\
\hline Constant & -0.809 & 0.411 & & -1.970 & 0.055 \\
\hline $\begin{array}{l}\text { Pedictor: } \\
\text { LnTA }\end{array}$ & 0.029 & 0.013 & 0.314 & 2.172 & 0.035 \\
\hline \multicolumn{6}{|c|}{ Langkah Kedua } \\
\hline \multicolumn{6}{|c|}{ Outcome: SRDI } \\
\hline Constant & 1.151 & 1.056 & & 1.091 & 0.282 \\
\hline $\begin{array}{l}\text { Pedictor: } \\
\text { LnTA }\end{array}$ & -0.021 & 0.034 & -0.092 & -0.608 & 0.547 \\
\hline \multicolumn{6}{|c|}{ Langkah Ketiga } \\
\hline Constant & -0.797 & 0.421 & & -1.892 & 0.065 \\
\hline $\begin{array}{l}\text { Mediator: } \\
\text { SRDI }\end{array}$ & -0.011 & 0.060 & -0.027 & -0.182 & 0.857 \\
\hline $\begin{array}{l}\text { Pedictor: } \\
\text { LnTA }\end{array}$ & 0.029 & 0.014 & 0.312 & 2.121 & 0.040 \\
\hline
\end{tabular}

Berdasarkan table 24 di atas diketahui nilai analisis regresi untuk mengetahui pengaruh antara ukuran perusahaan dengan kinerja keuangan bila di mediasi dengan pengungkapan sustainability report dengan hasil bahwa analisis regresi ukuran perusahaan terhadap kinerja keuangan menghasilkan nilai koefisien c sebesar 0.029. Serta jalur koefisien $\mathrm{c}$ diharapkan signifikan (nilai signifikansi $<0.05$ ), sehingga dapat dikatakan bahwa pada langkah pertama, total asset terpenuhi $(0.035<0.05)$. Sedangkan untuk hasil analisis regresi ukuran perusahaan terhadap pengungkapan Sustainability Report menghasilkan nilai koefisien a sebesar -0.021. Serta jalur koefisien a diharapkan signifikan (nilai signifikansi $<0.05$ ), sehingga dapat 
dikatakan bahwa pada langkah kedua, total asset tidak terpenuhi $(0.547>0.05)$.

Hasil dari analisis regresi ukuran perusahaan terhadap kinerja keuangan melalui pengungkapan Sustainability Report sebagai variabel mediasi menghasilkan nilai koefisien c' sebesar 0.029 dan nilai koefisien b sebesar 0.011. Jalur koefisien c' diharapkan tidak signifikan (nilai signifikansi > 0.05), sedangkan jalur koefisien $\mathrm{b}$ diharapkan signifikan (nilai signifikansi < 0.05). Sehingga, dapat dikatakan bahwa pada langkah ketiga, ukuran perusahaan dan SRDI tidak terpenuhi $(0.040<0.05 ; 0.857>$ 0.05). Berdasarkan hasil pengujian hipotesis $\left(\mathrm{H}_{5}\right)$, dapat diketahui bahwa $\mathrm{H}_{5}$ ditolak karena pada langkah pertama hasil analisis regresi terpenuhi, tetapi pada langkah kedua dan ketiga hasil analisis regresi tidak terpenuhi. Maka variabel pengungkapan Sustainability Report tidak dapat disebut sebagai pemediasi pengaruh antara ukuran perusahaan dan kinerja keuangan.

\section{Jumlah Rapat Komite Audit terhadap Kinerja Keuangan}

Mengacu pada prosedur pengujian peran variabel intervening yang dikemukakan oleh Baron dan Kenny (1986), maka berikut ini adalah langkah-langkah untuk mengetahui pengujian hipotesis $\left(\mathrm{H}_{8}\right)$ yang dilakukan dengan langkah-langkah berikut:

\begin{tabular}{|c|c|c|c|c|c|}
\hline \multirow{2}{*}{ Model } & \multicolumn{2}{|c|}{$\begin{array}{l}\text { Unstandardize } \\
\text { d Coefficients }\end{array}$} & \multirow{2}{*}{$\begin{array}{c}\begin{array}{c}\text { Standa } \\
\text { rdized } \\
\text { Coeffic } \\
\text { ients }\end{array} \\
\text { Beta }\end{array}$} & \multirow{2}{*}{$\mathbf{T}$} & \multirow{2}{*}{ Sig. } \\
\hline & B & $\begin{array}{l}\text { Std. } \\
\text { Error }\end{array}$ & & & \\
\hline \multicolumn{6}{|c|}{ Langkah Pertama } \\
\hline \multicolumn{6}{|c|}{ Outcome: ROA } \\
\hline Constant & 0,046 & 0,019 & & 2,501 & 0,016 \\
\hline \multicolumn{6}{|l|}{ Pedictor: } \\
\hline JRKA & 0,001 & 0,001 & 0,335 & 2,329 & 0,025 \\
\hline \multicolumn{6}{|c|}{ Langkah Kedua } \\
\hline \multicolumn{6}{|c|}{ Outcome: SRDI } \\
\hline Constant & 0,547 & 0,048 & & 11,428 & 0,000 \\
\hline $\begin{array}{l}\text { Pedictor: } \\
\text { JRKA }\end{array}$ & $\overline{0}, 001$ & 0,001 & 0,141 & $-0,932$ & 0,356 \\
\hline \multicolumn{6}{|l|}{ Langkah } \\
\hline \multicolumn{6}{|l|}{ Ketiga } \\
\hline \multicolumn{6}{|l|}{ Outcome: } \\
\hline \multicolumn{6}{|l|}{$\mathrm{ROA}$} \\
\hline Constant & 0,048 & 0,038 & & 1,281 & 0,207 \\
\hline Mediator: & - & 0,060 & $-0,009$ & $-0,058$ & 0,954 \\
\hline SRDI & 0,003 & & & & \\
\hline $\begin{array}{l}\text { Pedictor: } \\
\text { JRKA }\end{array}$ & 0,001 & 0,001 & 0,334 & 2,271 & 0,028 \\
\hline
\end{tabular}

Sumber: Data yang diolah (2018)
Berdasarkan tabel 25 di atas diketahui nilai analisis regresi untuk mengetahui pengaruh antara Corporate Governance melalui Jumlah Rapat Komite Audit dengan kinerja keuangan bila di mediasi dengan pengungkapan sustainability report dengan hasil bahwa analisis regresi Corporate Governance terhadap kinerja keuangan menghasilkan nilai koefisien c sebesar 0.001. Serta jalur koefisien $\mathrm{c}$ diharapkan signifikan (nilai signifikansi < 0.05), sehingga dapat dikatakan bahwa pada langkah pertama, jumlah rapat komite audit terpenuhi $(0.025<$ 0.05). Sedangkan untuk hasil analisis regresi Corporate Governance melalui jumlah rapat komite audit terhadap pengungkapan Sustainability Report menghasilkan nilai koefisien a sebesar -0.001 . Serta jalur koefisien a diharapkan signifikan (nilai signifikansi $<0.05$ ), sehingga dapat dikatakan bahwa pada langkah kedua, jumlah rapat komite audit tidak terpenuhi $(0.356>0.05)$.

Hasil dari analisis regresi Corporate Governance melalui jumlah rapat komite audit terhadap kinerja keuangan melalui pengungkapan Sustainability Report sebagai variabel mediasi menghasilkan nilai koefisien c' sebesar 0.001 dan nilai koefisien b sebesar 0.003 . Jalur koefisien c' diharapkan tidak signifikan (nilai signifikansi > 0.05), sedangkan jalur koefisien $b$ diharapkan signifikan (nilai signifikansi < 0.05). Sehingga, dapat dikatakan bahwa pada langkah ketiga, Corporate Governance dengan jumlah rapat komite audit dan SRDI tidak terpenuhi $(0.028<0.05 ; 0.954>$ 0.05). Berdasarkan hasil pengujian hipotesis $\left(\mathrm{H}_{8}\right)$, dapat diketahui bahwa $\mathrm{H}_{8}$ ditolak karena pada langkah pertama hasil analisis regresi terpenuhi, tetapi pada langkah kedua dan ketiga hasil analisis regresi tidak terpenuhi. Maka variabel pengungkapan Sustainability Report tidak dapat disebut sebagai pemediasi pengaruh antara Corporate Governance melalui jumlah rapat komite audit dan kinerja keuangan. 


\section{Jumlah Rapat Dewan Direksi terhadap Kinerja Keuangan}

Mengacu pada prosedur pengujian peran variabel intervening yang dikemukakan oleh Baron and Kenny (1986), maka berikut ini adalah langkah-langkah untuk mengetahui pengujian hipotesis $\left(\mathrm{H}_{9}\right)$ yang dilakukan dengan langkah-langkah berikut:

Tabel 26. Uji Mediasi III

\begin{tabular}{|c|c|c|c|c|c|}
\hline \multirow{2}{*}{ Model } & \multicolumn{2}{|c|}{$\begin{array}{l}\text { Unstandardized } \\
\text { Coefficients }\end{array}$} & \multirow{2}{*}{$\begin{array}{c}\begin{array}{c}\text { Standa } \\
\text { rdized } \\
\text { Coeffic } \\
\text { ients }\end{array} \\
\text { Beta }\end{array}$} & \multirow{2}{*}{$\mathbf{T}$} & \multirow{2}{*}{ Sig. } \\
\hline & B & $\begin{array}{c}\text { Std. } \\
\text { Error }\end{array}$ & & & \\
\hline \multicolumn{6}{|c|}{ Langkah Pertama } \\
\hline $\begin{array}{l}\text { Constant } \\
\text { Pedictor: }\end{array}$ & 0,065 & 0,026 & & 2,546 & 0,015 \\
\hline JRDD & 0,000 & 0,001 & 0,114 & 0,756 & 0,454 \\
\hline \multicolumn{6}{|c|}{ Langkah Kedua } \\
\hline Constant & 0,633 & 0,059 & & 10,648 & 0,000 \\
\hline $\begin{array}{l}\text { Pedictor: } \\
\text { JRDD }\end{array}$ & $-0,003$ & 0,001 & $-0,330$ & $-2,292$ & 0,027 \\
\hline \multicolumn{6}{|c|}{$\begin{array}{l}\text { Langkah Ketiga } \\
\text { Outcome: ROA }\end{array}$} \\
\hline Constant & 0,070 & 0,049 & & 1,424 & 0,162 \\
\hline $\begin{array}{l}\text { Mediator } \\
\text { : SRDI }\end{array}$ & $-0,008$ & 0,066 & $-0,020$ & $-0,122$ & 0,903 \\
\hline $\begin{array}{l}\text { Pedictor: } \\
\text { JRDD }\end{array}$ & 0,000 & 0,001 & 0,108 & 0,665 & 0,510 \\
\hline
\end{tabular}

Berdasarkan table 26 di atas diketahui nilai analisis regresi untuk mengetahui pengaruh antara Corporate Governance melalui jumlah rapat dewan direksi dengan kinerja keuangan bila di mediasi dengan pengungkapan sustainability report dengan hasil bahwa analisis regresi Corporate Governance jumlah rapat dewan direksi terhadap kinerja keuangan menghasilkan nilai koefisien c sebesar 0.000 . Serta jalur koefisien c diharapkan signifikan (nilai signifikansi $<0.05$ ), sehingga dapat dikatakan bahwa pada langkah pertama, jumlah rapat dewan direksi tidak terpenuhi (0.454 > 0.05). Sedangkan untuk hasil analisis regresi Corporate Governance melalui jumlah rapat dewan direksi terhadap pengungkapan Sustainability Report menghasilkan nilai koefisien a sebesar -0.003 . Serta jalur koefisien a diharapkan signifikan (nilai signifikansi < 0.05), sehingga dapat dikatakan bahwa pada langkah kedua, jumlah rapat dewan direksi terpenuhi $(0.027>0.05)$.

Hasil dari analisis regresi Corporate Governance jumlah rapat dewan direksi terhadap kinerja keuangan melalui pengungkapan Sustainability Report sebagai variabel mediasi menghasilkan nilai koefisien c' sebesar 0.000 dan nilai koefisien $b$ sebesar -0.008. Jalur koefisien c' diharapkan tidak signifikan (nilai signifikansi > 0.05), sedangkan jalur koefisien $b$ diharapkan signifikan (nilai signifikansi $<0.05$ ). Sehingga, dapat dikatakan bahwa pada langkah ketiga, Corporate Governance melalui jumlah rapat dewan direksi terpenuhi dan SRDI tidak terpenuhi $(0.510>0.05 ; 0.903>0.05)$. Berdasarkan hasil pengujian hipotesis $\left(\mathrm{H}_{9}\right)$, dapat diketahui bahwa $\mathrm{H}_{9}$ ditolak karena pada langkah kedua hasil analisis regresi terpenuhi, tetapi pada langkah pertama dan ketiga hasil analisis regresi tidak terpenuhi. Maka variabel pengungkapan Sustainability Report tidak dapat disebut sebagai pemediasi pengaruh antara Corporate Governance jumlah rapat dewan direksi dan kinerja keuangan.

\section{SIMPULAN DAN SARAN}

\section{Simpulan}

1. Ukuran perusahaan berpengaruh terhadap kinerja keuangan.

2. Corporate Governance yang diukur dengan jumlah rapat komite audit berpengaruh terhadap kinerja keuangan.

3. Corporate Governance yang diukur dengan jumlah rapat dewan direksi tidak berpengaruh terhadap kinerja keuangan.

4. Ukuran perusahaan tidak berpengaruh terhadap pengungkapan sustainability report.

5. Corporate Governance yang diukur dengan jumlah rapat komite audit tidak berpengaruh terhadap pengungkapan sustainability report.

6. Corporate Governance yang diukur dengan jumlah rapat dewan direksi berpengaruh terhadap pengungkapan sustainability report. 
7. Pengungkapan Sustainability Report tidak dapat memediasi hubungan antara ukuran perusahaan dengan kinerja keuangan.

8. Pengungkapan Sustainability Report tidak dapat memediasi hubungan antara Corporate Governance yang diukur dengan jumlah rapat komite audit dengan kinerja keuangan

9. Pengungkapan Sustainability Report tidak dapat memediasi hubungan antara Corporate Governance yang diukur dengan jumlah rapat dewan direksi dan kinerja keuangan.

\section{Saran}

1. Bagi peneliti selanjutnya diharapkan dapat menggunakan indikator lain selain jumlah rapat komite audit, jumalh rapat dewan direksi, dan Return On Asset untuk mengukur pengaruh variabel independen terhadap variabel dependen, serta menggunakan satu indeks GRI untuk menghitung skor Sustainability Report Disclosure Index misalnya hanya G4 atau GRI Standard saja. Selain itu, peneliti selanjutnya diharapkan pula dapat memperluas perolehan data; tidak hanya terbatas pada perusahaan Badan Usaha Milik Negara dan perusahaan sektor pertambangan.

2. Bagi investor dan calon investor diharapkan untuk memilih perusahaan yang tidak hanya baik dalam aspek ekonominya saja, tetapi juga baik dalam aspek sosial dan lingkungan. Hal ini dikarenakan kedua aspek tersebut diperlukan untuk mencapai keberlanjutan suatu perusahaan.

3. Bagi pemerintah Indonesia diharapkan dapat memberlakukan sebuah kebijakan baru di mana semua perusahaan diwajibkan untuk menjalankan tanggung jawab sosial dan lingkungan, agar seluruh sektor perusahaan lebih peduli terhadap keadaan sosial dan lingkungan perusahaannya.

\section{DAFTAR PUSTAKA}

Adhipradana, F., \& Daljono. (2014). Pengaruh Kinerja Keuangan, Ukuran Perusahaan,
Dan Corporate Governance Terhadap Pengungkapan Sustainability Report. Diponegoro Journal of Accounting Volume 3 Nomor 1 , 1-12.

Affan, H. (2018, April 4). Pencemaran tumpahan minyak di Teluk Balikpapan: "Sudah tiga hari kami mencium bau solar". Retrieved from https://www.bbc.com/indonesia/indonesi a-43626386

Aniktia, R., \& Khafid, M. (2015). Pengaruh Mekanisme Good Corporate Governance dan Kinerja Keuangan Terhadap Pengungkapan Sustainability Report. Accounting Analysis Journal 4(3), 3.

Antara News. (2009). Antara: 50 BUMN Berperingkat Buruk Pengelolaan Lingkungan. Retrieved from Kementrian Lingkungan Hidup Republik Indonesia: http://www.menlh.go.id/antara-50bumn-berperingkat-buruk-pengelolaanlingkungan/

Aulia, A. S., \& Syam, D. (2013). Pengaruh karakteristik perusahaan terhadap praktek pengungkapan sustainability reporting dalam laporan tahunan perusahaan publik di Indonesia. Jurnal Reviu Akuntansi dan Keuangan Vol. 3 No. 1, 403-414.

Badriyah, H. (2015). Buku Pintar Akuntansi Dasar untuk Orang Awam. Jakarta: Penerbit HB.

Bukhori, M. R. (2017). Pengaruh pengungkapan sustainability report terhadap kinerja keuangan. Sistem informasi, Keuangan, Auditing, dan Perpajakan Vol. 2 No. 1, 35-48.

Burhan, A. H., \& Rahmanti, W. (2012). The Impact Of Sustainability Reporting On Company Performance. Journal of Economics, Business, and Accountancy Ventura Volume 15 No. 2, 257-272.

Daniri, M. A. (2014). Lead by GCG. Jakarta: Gagas Bisnis.

Deegan, C. (2004). Financial Accounting Theory. Sydney: McGraw-Hill Book Company. 
Dewi, K. E., \& Sudana, I. P. (2015). Sustainability reporting dan profitabilitas (studi pada pemenang indonesian sustainability reporting awards). $E$ Jurnal Akuntantasi Universitas Udayana 12.3, 624 .

Donaldson, T., \& Preston, L. E. (1995). The Stakeholder Theory of the Corporation: Concepts, Evidence, and Implications. Academy of Management Review Vol. 20, No. 1, 65-91.

Ernst \& Young. (2016). Value of Sustainability Reporting: A study by EY and Boston College Center for Corporate Citizenship. Ernst \& Young LLP.

Freeman, R. E., \& Reed, D. L. (1983). Stockholders and Stakeholders: A New Perspective on Corporate Governance. Californian Management Review Vol. 25 No. 2, 88-106.

Ghozali, I. (2013). Aplikasi Analisis Multivariate dengan Program IBM SPSS 23. Semarang: Universitas Diponegoro.

Ghozali, I., \& Chariri, A. (2007). Teori Akuntansi. Semarang: Badan Penerbit Universitas Dipenegoro.

Global Reporting Initiative. (2013). PEDOMAN PELAPORAN KEBERLANJUTAN: Prinsip-prinsip Pelaporan dan Pengungkapan Standar. Amsterdam: www.globalreporting.org.

Global Reporting Initiative. (2018, Maret 6). Sustainability Reporting. Retrieved from globalreporting:

https://www.globalreporting.org/informa tion/sustainability-

reporting/Pages/reporting-benefits.aspx

Hasanah, N., Syam, D., \& Jati, A. W. (2015). Pengaruh Corporate Governance terhadap Pengungkapan Sustainability Report pada Perusahaan di Indonesia. Jurnal Reviu Akuntansi dan Keuangan, 711-720.

Hery. (2015). Analisis Laporan Keuangan. Yogyakarta: Center for Academic Publishing Service.
Idah. (2013). Corporate governance dan karakteristik perusahaan dalam pengengkupan sustainability report. Accounting Analysis Journal 2 (3).

Isbanah, Y. (2015). Pengaruh ESOP, Leverage, dan Ukuran Perusahaan terhadap Kinerja Keuanfan Perusahaan di Bursa Efek Indonesia. Journal of Research in Economics and Management Volume 15 No. 1, 28-41.

Karsam. (2017). Pengaruh strategi bisnis terhadap sistem pengendalian manajemen - studi pada BUMN Kategori Industri Strategis di Indonesia. Jurnal Dinamika Akuntansi dan Bisnis Vol. 4(1), 113.

Khafid, M., \& Mulyaningsih. (2015). Kontribusi karakteristik perusahaan dan corporate governance terhadap publikasi sustainability. Ekuitas: Jurnal ekonomi dan Keuangan Volume 19 Nomor 3, 341.

Komite Nasional Kebijakan Governance. (2002, Mei 30). Dokumen Pedoman. Retrieved from Komite Nasional Kebijakan Governance: $\quad$ www.knkgindonesia.org/dokumen/PedomanKomite-Audit.pdf

Komite Nasional Kebijakan Governance. (2006). Pedoman Umum Good Corporate Governance Indonesia.

Kuncoro, M. (2011). Metode Kuantitatif: Teori dan Aplikasi untuk Bisnis dan Ekonomi. Yogyakarta: Unit Penerbit dan Percetakan Sekolah Tinggi Ilmu Manajemen YKPN.

Luciana , A. (2018, April 10). TEMPO.CO. Retrieved from DPRD Penajam: Pertamina Siap Ganti Rugi Pencemaran Minyak: https://bisnis.tempo.co/read/1078028/dpr d-penajam-pertamina-siap-ganti-rugipencemaran-minyak/full\& view $=$ ok

Media Indonesia. (2016, Desember 15). 120 Perusahaan Terbitkan Laporan Berkelanjutan. Retrieved from Media Indonesia: http://mediaindonesia.com/news/read/82 
857/120-perusahaan-terbitkan-laporanberkelanjutan/2016-12-15

Muallifin, O. R., \& Priyadi, M. P. (2016). Dampak Pengungkapan Sustainability Report terhadap kinerja keuangan dan kinerja pasar. Jurnal Ilmu dan Riset Akuntansi: Volume 5 Nomor 5, 1-20.

Nasir, A., Ilham, E., \& Utara, V. I. (2014). Pengaruh karakteristik perusahaan dan corporate governance terhadap pengungkapan sustainability report pada perusahaan LQ45 yang terdaftar . Jurnal Ekonomi Volume 22 Nomor 1, 1-18.

Pikiran Rakyat. (2017, Desember 21). Pemprov Jabar Apresiasi Industri Taati Aturan Lingkungan Hidup. Retrieved from Pikiran Rakyat: http://www.pikiranrakyat.com/jawabarat/2017/12/21/pemprov-jabarapresiasi-industri-taati-aturanlingkungan-hidup-416356

Pos Kota. (2016, Desember 19). Laporan Keberlanjutan Perusahaan Masih Sukarela. Retrieved from Poskotanews: http://poskotanews.com/2016/12/19/lapo ran-keberlanjutan-perusahaan-masihsukarela/

Prahadi, Y. Y. (2015, Juni 18). Bikin Laporan Keberlanjutan, Ini Manfaatnya Buat Perusahaan. Retrieved from SWA: https://swa.co.id/swa/trends/managemen t/bikin-laporan-keberlanjutan-inimanfaatnya-buat-perusahaan

Putra, W. (2018, Mei 3). Perusahaan BUMN di Subang Diduga Buang Limbah Sembarangan. Retrieved from MEDIAJABAR.COM:

https://www.mediajabar.com/daerah/per usahaan-bumn-di-subang-diduga-buanglimbah-sembarangan.html

Ross, S., R, W., \& B, J. (2003). Fundamental of Corporate Finance Sixth Edition. Singapore: McGraw-Hill Book Company.

Saragih, J. P. (2014). politik dan ekonomi kebijakan privatisasi badan usaha milik negara. Journal Ekonomi dan Pembangunan Vol. 22 No. 1, 84.

Sari, M. P., \& Marsono. (2013). Pengaruh kinerja keuangan, ukuran perusahaan, dan corporate governance terhadap pengungkapan sustainability report. Diponegoro Journal of Accounting Volume 2 Nomor 3, 2.

Sekaran, U., \& Bougie, R. (2017). Metode Penelitian untuk Bisnis Edisi 6 Buku 1. Jakarta: Salemba Empat.

Setiawan, A. (2016). Pengaruh corporate governance terhadap kinerja keuangan perusahaan. Jurnal SIKAP Vol. 1 No.1, $1-8$.

Solomon, J. (2013). Corporate Governance and Accountability . United Kingdom: John Wiley \& Sons Ltd.

Sugiyono. (2012). Metode Penelitian: Kuantitatif, Kualitatif, dan $R \& D$. Bandung: Penerbit Alfabeta.

Sugiyono. (2014). Metode Penelitian Manajemen. Bandung: Penerbit Alfabeta.

Sujarweni, V. W. (2016). Kupas Tuntas Penelitian Akuntansi dengan SPSS. Yogyakarta: Pustaka Baru Press.

Sutrisno. (2013). Manajemen Keuangan: Teori, Konsep \& Aplikasi. Yogyakarta: Penerbit Ekonisia Fakultas Ekonomi UII.

Tambunan, J. T., \& Prabawani, B. (2018). Pengaruh ukuran perusahaan, leverage dan struktur modal terhadap kinerja keuangan perusahaan. Diponegoro Journal of Social and Politic, 1-10〉.

Taringan, J., \& Semuel, H. (2014). Penungkapan Sustainabilty report dan kinerja keuangan. Jurnal Akuntansi dan Keuangan Vol.16 No. 2, 88-101.

Torang, S. (2014). Organisasi \& Manajemen: Perilaku, Struktur, Budaya \& Perubahan Organisasi. Bandung: Penerbit Alfabeta.

Tumewu, J. (2017). Pengaruh karakteristik perudahaan dan corporate governance terhadap praktik publikasi sustainability 
report pada perusahaan publik di Indonesia. Jurnal Ilmiah Akuntansi Fakultas Ekonomi Volume 3 No. 1, 1-19.
Wijayanti, R. (2016). Pengaruh Pengungkapan Sustainability Report terhadap Kinerja Keuangan Perusahan. Syariah Paper Accounting FEB UMS, 39-51. 